\title{
Scenarios of Robot Assisted Play for Children with Cognitive and Physical
}

\section{Disabilities}

\author{
Ben Robins $^{\mathrm{a}}{ }^{*}$, Kerstin Dautenhahn ${ }^{\mathrm{a}}$, Ester Ferrari ${ }^{\mathrm{a}}$, Gernot Kronreif ${ }^{\mathrm{b}}$, Barbara Prazak-Aram ${ }^{\mathrm{c}}$, \\ Patrizia Marti $^{\mathrm{d}}$, Iolanda Iacono ${ }^{\mathrm{d}}$, Gert-jan Gelderblom ${ }^{\mathrm{e}}$, Bernd Tanja ${ }^{\mathrm{e}}$, Francesca Caprino ${ }^{\mathrm{f}}$, \\ Elena Laudanna ${ }^{\mathrm{f}}$ \\ ${ }^{a}$ Adaptive Systems Research Group, University of Hertfordshire, U.K. \\ ${ }^{\mathrm{b}}$ Austrian Center for Medical Innovation and Technology, Austria \\ ${ }^{\mathrm{c}}$ AIT Austrian Institute of Technology GmbH, Austria \\ ${ }^{\mathrm{d}}$ University of Sienna, Italy \\ ${ }^{\mathrm{e}}$ Zuyd University, Research Centre for Technology in Care, The Netherlands \\ ${ }^{\mathrm{f}}$ University of Valle d'Aosta, Italy
}

\begin{abstract}
This article presents a novel set of ten play scenarios for robot assisted play for children with special needs. This set of scenarios is one of the key outcomes of the IROMEC project that investigated how robotic toys can become social mediators, encouraging children with special needs to discover a range of play styles, from solitary to collaborative play (with peers, carers/teachers, parents etc). The target user groups in the project were children with Mild Mental Retardation ${ }^{1}$, children with Severe Motor Impairment and children with Autism. The play scenarios were developed against specific educational and therapeutic objectives that were discussed with panels of experts (teachers therapists parents) in various countries, during several user panel meetings for each of the above mentioned target user groups. These objectives were
\end{abstract}

\footnotetext{
${ }^{1}$ The term Mental Retardation was replaced in the UK by the Disability Discrimination Act, with the term Learning Difficulties. However, as it is still being widely used in continental Europe, this was the term chosen to be used within the IROMEC project
} 
classified with reference to the ICF-CY, the International Classification of Functioning version for Children and Youth. The article presents a detailed description of the play scenarios, each with its relevant educational and therapeutic objectives in five key developmental areas (i.e sensory development, communication and interaction, cognitive development, motor development and social and emotional development). While the play scenarios described in this paper originally were developed for and tested with the above user groups and with the IROMEC robot, the play scenarios can potentially be applied to other user groups and to a wide range of other applications involving human-robot interaction using different robotic toys.

\section{Introduction}

The work presented in this article was developed as part of the FP6 European project IROMEC ${ }^{2}$ that investigated how robotic toys can become social mediators (IROMEC, 2010). The project's state of the art research emphasised the important role of play in child development as a crucial vehicle for learning about the physical and social environment, the self and for developing social relationships. IROMEC targeted children who are prevented from playing, either due to cognitive, developmental or physical impairments which affect their playing skills, leading to general impairments in their learning potential and more specifically resulting in isolation from the social environment. The target user groups in the project were children with Mild Mental Retardation, children with Severe Motor Impairment and children with Autism.

The crucial role of play in a child's development has been widely accepted. The World Health Organisation in its ICF-CY (International Classification of Functioning and Disabilities, version for Children and Youth) publication considers play as one of the most important aspect of a child's life to be considered when assessing children's quality of life (WHO, 2001). During play children can learn about themselves and their environments as well as develop cognitive, social

\footnotetext{
2 The work described in this article was conducted within the EU project IROMEC (Interactive Robotic Social Mediators as Companions) and was co-funded by the European Commission in the 6th Framework Program under contract IST-FP6-045356.
} 
and perceptual skills (Ferland, 1977). The literature suggests that play is an essential activity during childhood, and that its absence provides an obstacle to the development of a healthy child possibly leading to general impairment in their learning potential and cognitive development and may result in isolation from the social environment (Bruner et al., 1972; Piaget, 1962; Vygotsky, 1978; Winnicott, 1971).

For children with special needs, play can be a difficult experience, as they might have limited access to this activity and may show subsequent problems in skill acquisition in various developmental areas. However, their cognitive and social development can be improved by giving them the same play opportunities as their typically-developed peers. In order to do so, it is important to provide them with the right stimuli for their developmental levels, strengths and needs. In that sense, robotic systems can be a valuable tool for children with special needs to learn through play interactions and can help them to reach the developmental steps of their chronological and/or mental ages (Besio., 2001).

The IROMEC project investigated how robotic toys could provide such opportunities for learning and enjoyment. The developed play scenarios and a newly designed robotic system ${ }^{3}$ were tailored towards becoming a social mediator, empowering children with disabilities to discover the range of play styles from solitary to social and cooperative play (with peers, carers/teachers, parents etc).

In recent years there have been many examples of robots being used to involve children with special needs in play activities for therapeutic or educational purposes. Research shows that robots can provide a focus of attention (Werry et al., 2001) and promote spontaneous play in children with developmental disorders (Kozima et al., 2007). Remotely controlled robotic systems being used in rehabilitation (Lathan \& Malley, 2001), artificial pets such as the baby seal Paro (Marti et al., 2005) the teddy bear Huggable (Stiehl et al., 2005), small, simple creature-like robots such as Keepon (Kozima et al., 2007) and the huggable creature-like Probo

\footnotetext{
${ }^{3}$ The robot developed within the IROMEC project is called the "IROMEC robot" in this article. We do not provide details of this robot in this publication since the scenarios developed for this robot, which are the focus on this work, are not restricted to the specific IROMEC robot. For details of the robot see Marti et al., (2009).
} 
(Saldien et al., 2008), humanoid robots such as the robotic doll Robota (Robins et al., 2005; Robins et al., 2004a; Robins et al., 2004b), the humanoid structure on wheels Tito (Michaud et al., 2007) and the child-like KASPAR (Dautenhahn et al., 2009) have all been used to engage children in playful interactions and helped them in developing social skills.

The added value of the play scenarios presented in this article is that they have been developed in close consultation with several panels of experts (therapists, teachers, parents) to cover the play needs of children with a variety of disabilities (e.g. cognitive impairments, physical impairments, developmental impairments) taking the children's specific strengths and needs into consideration. The play scenarios were developed with specific therapeutic and educational objectives in five key developmental areas: sensory development, communication and interaction development, motor development, cognitive development and social and emotional development. The play scenarios presented in this paper are on the one hand specific enough to allow implementation by other researchers, but on the other hand are sufficiently generic to be adapted to different user groups and different robotic systems.

As stated above, the main aim of this article is to present the comprehensive and previously unpublished set of play scenarios in detail (see section 2). The remainder of this section briefly summarizes the developmental process that ultimately leads to the play scenarios. Full details of this process can be found in Ferrari et al. (2009); Robins et al. (2010b); Robins et al. (2007).

\subsection{Target user groups and expert user panels}

At the onset of the IROMEC project, different main user groups were considered (e.g. children with physical impairments such as Cerebral Palsy, Spina Bifida, Motor impairment, children with cognitive impairments such as Autistic Spectrum Disorders, children with cognitive disabilities such as mental retardation, Down syndrome, etc.). At the same time, several panels of experts made up by 45 professionals from different medical centres and special education schools, including teachers, medical doctors, therapists (e.g. psychotherapists, speech therapists, play therapists, physiotherapists, occupational therapists, neuro-psychologists), as well 
as parents and family members, were organized by the project's partners in different European countries (i.e. Spain, Italy, The Netherlands, Austria, UK). These panels were related to different end-user groups (children with different disabilities; e.g. physical disabilities, cognitive disabilities, autism), and were set with the aim to inform and provide feedback at every stage of the project from eliciting the requirement of the various user groups, to developing play scenarios against specific therapeutic and educational objectives. As an example, the UK panel involved professionals from different schools, as well as parents and family members of children with autism. The panel consisted of 7 teachers from 3 different schools, 5 therapists (psychotherapist, speech therapist, play therapist, physiotherapist, occupational therapist) and two parents and family members. More details on the set-up and the role of all the user panels can be found in Gelderblom et al. (2007); Robins et al. (2007).

The discussion with the panel of experts showed high correlation in needs between some of the above target user groups and identified two main target groups: the physically impaired group of children and children with cognitive impairments. It was found that by focussing on these two main groups, many needs of other user groups can also be addressed. The final selection of user groups consisted of:

- $\quad$ AUT - children with autism

- $\quad$ MMR - children with mild mental retardation

- $\quad$ SMI - children with severe motor impairment

\subsection{Scenarios design process}

The development process of the play scenarios (see Figure 1) is based on a user-centred perspective. After the initial phase of an extended literature review related to existing technology used in play activities, the play scenarios have been developed based on information from the users panels regarding play activities, limitations, needs and the range of interactions that robotic devices can facilitate. 


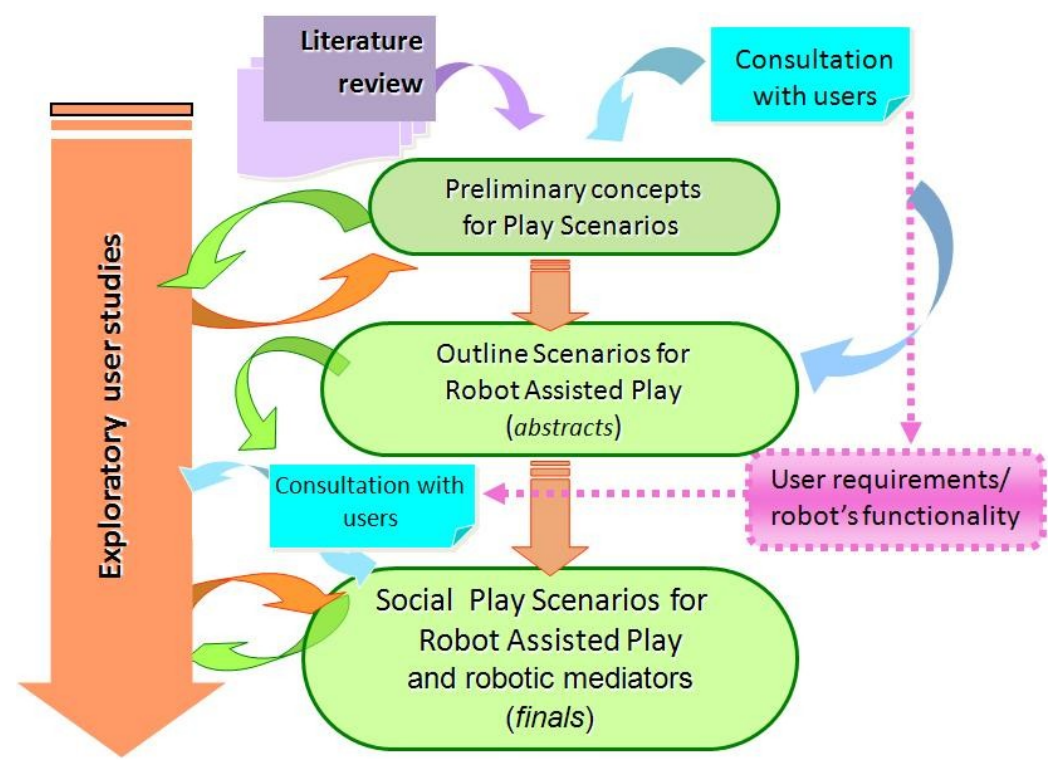

Figure 1. Developmental process of scenarios for robot assisted play, based on Robins et al. (2010)

The involvement of the users took place throughout the different stages of development of both the play scenarios and the robotic platform. From the very beginning, the panel of experts provided the understanding of children's needs from the various user groups, helping eliciting the requirements through regular feedback on ongoing design iterations and at the end of the project (verification and user validation).

The play scenarios were developed in three phases:

I) preliminary concept of play scenarios

II) outline scenarios (abstract)

III) social play scenarios (final)

Ongoing consultations with panels of experts (Ferrari et al., 2009; Robins et al., 2010b) have been conducted to collect information related to the play activities of children with special needs. They informed the design process about the children's likes, dislikes, abilities and needs, and the ways the experts envisage the use of robotic toys in therapy or education.

Given the nature of the children's impairments, children were not directly included in the user panels; instead, the involvement of the children occurred during experimental investigations where specific aspects of the scenarios were tested as part of phase I. Different aspects of the 
user requirements, as expressed in these user panel meetings were subsequently implemented in experimental play scenarios that focussed on specific play activities and were investigated in field trials using existing available technology.

In Phase II the feedback from the above experimental investigations, in conjunction with the outcome of further consultation with the panel of expert users, were then merged to form the Outline Play Scenarios. These are abstract scenarios that reflect the user requirements and are not related to any specific technological solution/robot.

In phase III the Outline Play Scenarios were further developed in consultation with the panel of experts against specific therapeutic and educational objectives. Taking also into account results of ongoing experimental investigations of the different functionalities of the IROMEC robot that took place with the different target user groups, the final set of play scenarios was developed. These are the Social Play Scenarios for robot assisted play that are reported here. Further description of the various stages of the scenarios' design process including examples from the exploratory user studies can be found in Robins et al. (2010b).

The remainder of this article is structured as follows. The next section (2) represents the main novel contribution of this article, namely a detailed description of the final IROMEC play scenarios. Section 3 illustrates the use of some of these scenarios in an exploratory human-robot interaction study involving a small group of children with special needs. Conclusion and future work are discussed in section 4.

\section{Social Play Scenarios for Robot Assisted Play and Robotic Mediators}

Ten play scenarios for robot assisted play and robotic mediator were developed (see Figure 2), adopting the ESAR system (Garon et al., 1996) that identifies four different types of play ${ }^{4}$. These types of play help children to socialize by teaching them how to take turns, observe rules and respect the opinions and actions of fellow players. Moreover, they have a vital role in

\footnotetext{
${ }^{4}$ The four types of play are: exercise play, assembling play, symbolic play, and games with rules.
} 
acquiring different types of knowledge and skills, and helping to develop basic interaction functions, memory, attention, communication functions, perceptual and motor skills.

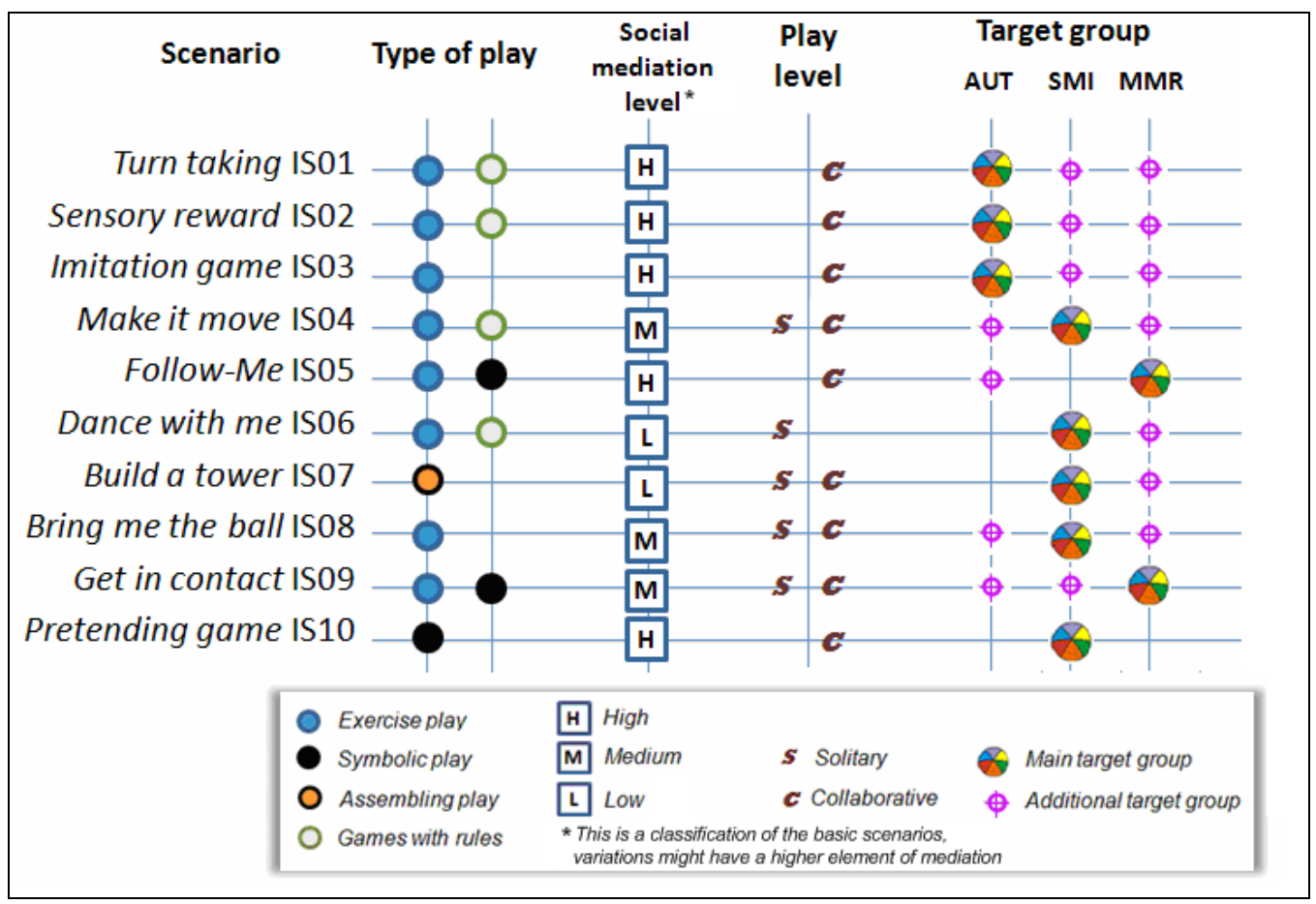

Figure 2 IROMEC Play Scenarios

Two different symbols ( $\otimes$ and $\phi$ ) have been used in Figure 2. For each scenario they indicate the main target group (®), and the additional target user groups, if any $(\phi)$. The main target group is the one for which a scenario has mainly been developed, while the additional ones are the target user groups that can still benefit from playing it. As mentioned above, it is thought that these play scenarios are not limited to the IROMEC's target user groups only (i.e. AUT, SMI and MMR) and could also benefit other users with special needs.

For each scenario, a comprehensive set of therapeutic and educational objectives has been drawn on, in close collaboration with therapists and teachers. These objectives have been 
developed according to the ICF-CY classification (WHO, 2001).

\subsection{IROMEC Play Scenarios}

The IROMEC scenarios are higher level conceptualizations of the 'use of the robot in a particular context'. The scenarios have the form of textual narratives describing an activity in its context. Their structure has been adopted and modified from the scenario based design methodology (Carroll, 1995; Rosson \& Carroll, 2002; Rozzo et al., 2003) and consists of the description of actors and their roles, the type of play, the description of the activity, the recursive model, the place and setting, the robot configuration, and the duration of the activity.

All the IROMEC play scenarios can be played in an educational, therapeutic, or home setting, where the second player can be an adult (e.g. teacher, therapist, family member, etc) or a child (with or without special needs). As a general note, in the scenarios where the robot is placed on a table, the robot's movement on the table is disabled for safety reasons.

The next sections detail the ten IROMEC play scenarios and their variations. Each play scenario is followed by a list of the identified therapeutic and educational objectives relevant to that specific scenario.

\subsubsection{Scenario IS01 "Turn-taking with a mobile robot"}

The IS01 play scenario is an exercise play with very simple rules. It consists of a collaborative turn-taking activity with a mobile robot. It has mainly been developed to be played by low functioning children with autism, but it can also be played by children with SMI and MMR. Four variations of the basic scenario have been developed.

\section{BASIC SCENARIO}

Main target user group: AUT 
Additional target user groups: SMI, MMR

\begin{tabular}{|l|l|}
\hline Play Type & Exercise play, very simple game with rules. \\
\hline Actors & $\begin{array}{l}\text { Two actors are involved in the game. } \\
\text { These actors could be a child and an adult, or two children. }\end{array}$ \\
\hline Activity & $\begin{array}{l}\text { The game consists of a collaborative turn-taking activity with a mobile robot. The } \\
\text { mobile robot has a start/stop activation mechanism that can be controlled by the user. } \\
\text { Sitting on the floor at a distance from each other, the first player turns the robot to face } \\
\text { the second player and presses the start button causing the robot to move toward the } \\
\text { second player. } \\
\text { When the robot reaches a predefined distance from the second player, it stops. The } \\
\text { player then turns it around, presses the start button and sends it back towards the first } \\
\text { player. }\end{array}$ \\
\hline Setting & $\begin{array}{l}\text { The game is played on the floor in a room with a large empty space. } \\
\text { Time }\end{array}$ \\
\hline $\begin{array}{l}\text { The game is made up of a short sequence of actions. The basic phase can repeat itself } \\
\text { many times, thus the duration of the activity is unlimited and can take place as long as } \\
\text { the participants are interested. }\end{array}$ \\
$\begin{array}{l}\text { A mobile robot with a start/stop user interface mechanism that also includes status and } \\
\text { sensory displays (light, sounds, etc.). }\end{array}$ \\
\hline
\end{tabular}

\section{VARIATIONS:}

\section{Variation 1 - Player positions}

\begin{tabular}{|c|c|}
\hline $\begin{array}{l}\text { Target } \\
\text { group }\end{array}$ & AUT - MMR - SMI \\
\hline Activity & $\begin{array}{l}\text { players positions (depending on the ability of the child) } \\
\text { During the activity the players change their position. For example: } \\
\text { a) the player who is waiting for the robot can go to a different position in the room } \\
\text { before giving the instruction to 'release' the robot, and the player with the robot } \\
\text { needs to aim it at the new position of the other player; } \\
\text { b) one of the players can choose/declare where s/he will direct the robot and } \\
\text { ask/request the other player to move and change his/her position so the robot can } \\
\text { reach him/her. }\end{array}$ \\
\hline Setting & $\begin{array}{l}\text { The game is played on the floor in a room with a large empty space that can allow the } \\
\text { participants to go to different points in the room, or to run around and wait in anticipation } \\
\text { for the robot to reach them. }\end{array}$ \\
\hline
\end{tabular}

Variation 2 - Game's rule

\begin{tabular}{|l|l|}
\hline Target group & AUT - MMR - SMI \\
\hline Activity & $\begin{array}{l}\text { > introduce a new rule (depending on the ability of the child) } \\
\text { The player with the robot has to wait for an instruction (e.g. "Go", clapping of the } \\
\text { hands, etc) from the other player before 'releasing' the robot (the instruction signal is } \\
\text { not aimed at the robot itself; it is aimed at the other player, telling him/her when to } \\
\text { 'release' the robot). }\end{array}$ \\
\hline
\end{tabular}

Variation 3 - Group of players

\begin{tabular}{|l|l|}
\hline Target group & AUT - MMR - SMI \\
\hline Actors & $\begin{array}{l}\text { > number of players } \\
\text { Instead of two players, the activity can involve a group of children. }\end{array}$ \\
\hline Activity & $\begin{array}{l}\text { The player with the robot has to choose and aim the robot towards one of the other } \\
\text { players. }\end{array}$ \\
\hline
\end{tabular}


Variation 4- Two remote controls

\begin{tabular}{|c|c|}
\hline Target group & SMI - MMR \\
\hline Activity & $\begin{array}{l}\text { The users are controlling the robot via remote control. } \\
\text { Sitting on their wheelchairs at a distance from each other, the first player by using } \\
\text { his/her remote control 'sends' the robot toward the second player. } \\
\text { When the robot reaches the second player it stops. } \\
\text { The second player then turns and 'sends' the robot (using his/her remote control) back } \\
\text { towards the first player. }\end{array}$ \\
\hline $\begin{array}{l}\text { Additional } \\
\text { Robot } \\
\text { characteristics }\end{array}$ & $\begin{array}{l}\text { Two remote controls to activate the robot (one for each player) } \\
\text { - Two buttons on each remote control: one to make the robot move and one to } \\
\text { turn it in order to face the other player (there isn't a 'stop button' to stop the } \\
\text { robot movement - it stops when reach the player) } \\
\text { - } \quad \text { Remote control functionality for robot (turn and start movements) } \\
\text { - } \quad \text { Remote controls toggle active/passive status } \\
\text { - } \quad \text { Light feedback: e.g. the button is illuminated when active - not illuminated } \\
\text { when inactive. The robot reacts only if the player presses the button when it is } \\
\text { active. Once a button has been pressed, it turns inactive and the button on the } \\
\text { other remote control turns active. }\end{array}$ \\
\hline
\end{tabular}

\section{Objectives:}

\begin{tabular}{|c|c|c|c|c|}
\hline Area & Educational and therapeutic objectives & AUT & SMI & MMR \\
\hline \multirow{2}{*}{ 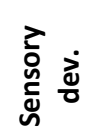 } & $\begin{array}{l}\text { Perceptual functions } \\
\bullet \quad \text { to improve visual perception }\end{array}$ & $\phi$ & & \\
\hline & - to improve visual spatial awareness & - & & - \\
\hline \multirow{9}{*}{ 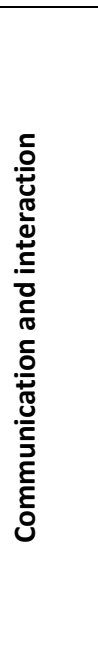 } & $\begin{array}{l}\text { Communicating - producing - nonverbal messages } \\
\text { - to improve non verbal aspects such as gestures and pointing }\end{array}$ & $\phi$ & & $\epsilon$ \\
\hline & $\begin{array}{l}\text { Basic interpersonal interaction } \\
\text { - to improve turn-taking }\end{array}$ & - & $\theta$ & $\phi$ \\
\hline & - to foster taking initiative & 0 & 0 & \\
\hline & - to improve gaze shift and eye contact with others & $\phi$ & & $\phi$ \\
\hline & - to improve level of response to social cues & $\phi$ & & \\
\hline & - to improve level of response to others & 0 & & $\phi$ \\
\hline & $\begin{array}{l}\text { Particular interpersonal relationships } \\
\text { - to establish a therapeutic alliance }\end{array}$ & $\phi$ & & $\phi$ \\
\hline & - $\quad$ to foster a therapeutic relationship & $\phi$ & & \\
\hline & - $\quad$ to encourage participation with classmates & 0 & $\phi$ & $\phi$ \\
\hline \multirow{2}{*}{ 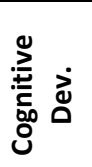 } & $\begin{array}{l}\text { Global intellectual functions } \\
\text { • to improve understanding of cause and effect }\end{array}$ & - & - & $€$ \\
\hline & $\begin{array}{l}\text { Higher-level cognitive functions } \\
\qquad \quad \text { to improve organization and planning } \rightarrow \text { VARIATION } 1\end{array}$ & & $\phi$ & $\phi$ \\
\hline
\end{tabular}




\begin{tabular}{|c|c|c|c|c|}
\hline Area & Educational and therapeutic objectives & AUT & SMI & MMR \\
\hline & $\begin{array}{l}\text { Attention } \\
\text { - to improve focusing attention }\end{array}$ & $\phi$ & $\phi$ & $\phi$ \\
\hline & - to improve the ability to maintain attention & $\phi$ & $\phi$ & $\phi$ \\
\hline & - to improve joint attention & $\phi$ & $\phi$ & $\phi$ \\
\hline & Thinking & & $\phi$ & $\phi$ \\
\hline \multirow{2}{*}{ 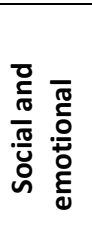 } & $\begin{array}{l}\text { Engagement in play } \\
\qquad \quad \text { to foster shared cooperative play }\end{array}$ & $\phi$ & $\theta$ & $\phi$ \\
\hline & $\begin{array}{l}\text { Community social and civic life } \\
\text { - to improve the ability to understand and apply play rules } \rightarrow \\
\text { VARIATION } 1 \& 2\end{array}$ & $\phi$ & & $\phi$ \\
\hline ㅎํㄹ & $\begin{array}{l}\text { Mobility (fine hand use) } \\
\text { - to improve coordinated hand use }\end{array}$ & & $\phi$ & \\
\hline
\end{tabular}

\subsubsection{Scenario IS02 "Turn-taking for sensory reward"}

The IS02 play scenario is an exercise play with very simple rules. It consists of a collaborative turn-taking activity with sensory rewards. The scenario has mainly been developed to be played by children with autism as a collaborative play, but it can also be played by children with SMI and MMR. Two variations of the basic scenario have been developed.

\section{BASIC SCENARIO}

Main target user group: AUT

Additional target user groups: SMI - MMR

\begin{tabular}{|c|c|}
\hline Play Type & Exercise play, very simple game with rules. \\
\hline Actors & $\begin{array}{l}\text { Two actors are involved in the scenario. These actors could be a child and an adult, or } \\
\text { two children. }\end{array}$ \\
\hline Activity & $\begin{array}{l}\text { The game consists of a collaborative turn-taking activity with sensory rewards. There } \\
\text { are two different input channels such buttons to activate (in the way of 'cause and } \\
\text { effect') a corresponding sensory output display (e.g. coloured light display, sounds, } \\
\text { etc.). } \\
\text { The robot has two rows of } 3 \text { coloured lights each (e.g., a row with } 3 \text { red lights and a row } \\
\text { with } 3 \text { green lights), and two play buttons, one for each player. The players have to } \\
\text { press their 'own' button in turns, in order to activate the lights in the row that } \\
\text { corresponds to them. } \\
\text { Sitting on the floor close to the robot, one player starts the game by pressing a button } \\
\text { on one side of the robot. As a result a coloured light (e.g. red) goes on. } \\
\text { The other player presses in his/her turn another button on the other side of the robot, } \\
\text { and as a result a different coloured light (e.g. green) goes on. } \\
\text { The first player presses again the first button and another red light goes on in 'his' row. } \\
\text { The other player then presses again the button s/he pressed before and another green } \\
\text { light goes on. } \\
\text { This continues three times, thus the players see a visual progression in the rows of } \\
\text { lights towards the end. }\end{array}$ \\
\hline
\end{tabular}




\begin{tabular}{|l|l|}
\hline & $\begin{array}{l}\text { Then when the first player (the one who started the game) presses again 'his/her' } \\
\text { button something different and new occurs: a major sensory reward of a kind (e.g. a } \\
\text { white light flashes on/off, sounds and movement). } \\
\text { Each button need to be pressed in turn otherwise the robot will not respond. } \\
\text { The whole sequence can be repeated, and the players can swap roles, i.e. the player } \\
\text { that started first, now starts second. } \\
\text { As this is a very repetitive game, the adult may introduce variations in the way the } \\
\text { game is played (e.g. calling out the colour of the light, etc.). }\end{array}$ \\
\hline Setting & $\begin{array}{l}\text { The game is played on the floor/carpet. } \\
\text { The robot is placed on the floor and the participants are sitting around it. } \\
\text { In this context, the players are likely to move around it, so there needs to be enough } \\
\text { space around them. }\end{array}$ \\
\hline Time & $\begin{array}{l}\text { The game is made up of a short sequence of actions. } \\
\text { The basic sequence can repeat itself many times, thus the duration of the activity is } \\
\text { unlimited and can continue as long as the participants are interested. } \\
\text { Also there is no time restriction on how quickly the buttons need to be pressed. }\end{array}$ \\
\hline Robot \\
configuration
\end{tabular} \mid \begin{tabular}{l} 
A stationary robot (no movement in space, but possible turning around on the \\
spot as part of the sensory reward) \\
Inputs: two buttons on opposite sides of the robot. \\
$-\quad \begin{array}{l}\text { Visual feedback: two rows of coloured lights (e.g. one row of red lights and one } \\
\text { row of green lights). } \\
\text { Additional major sensory output }{ }^{5} \text { It is important that the final reward can be } \\
\text { adjusted according to the needs and preferences of a specific child. }\end{array}$ \\
\hline
\end{tabular}

\section{VARIATIONS:}

\section{Variation 1 - Two remote controls}

\begin{tabular}{|l|l|}
\hline Target group & SMI - MMR \\
\hline Activity & $\begin{array}{l}\text { The players have a remote control to activate the lights on the robot. } \\
\text { Sitting on the floor, the first player presses a button on his/her remote control and as a } \\
\text { result a coloured light on one of the rows of lights on the robot goes on (e.g. red light); } \\
\text { the second player presses a button which activates a light on the other coloured row } \\
\text { of lights (e.g. green light). }\end{array}$ \\
\hline $\begin{array}{l}\text { Additional } \\
\text { robot } \\
\text { characteristics }\end{array}$ & $\begin{array}{l}\text { In the basic scenario there are two buttons (one for each player) on the robot. In this } \\
\text { variation, two remote controls are used (one for each player), replacing the need of } \\
\text { pressing the buttons on the robot. }\end{array}$ \\
& $-\quad$ Remote controls with one coloured button each \\
& $-\quad$ Remote controls toggle active/passive status \\
\hline
\end{tabular}

\section{Variation 2 - Numbers of turns}

\begin{tabular}{|l|l|}
\hline $\begin{array}{l}\text { Target } \\
\text { group }\end{array}$ & AUT $-\mathrm{MMR}-\mathrm{SMI}$ \\
\hline Activity & $\begin{array}{l}\text { In the basic scenario the additional major sensory output goes on after } 3 \text { turns. The } \\
\text { complexity of the activity can be adjusted by increasing or decreasing the numbers of } \\
\text { turns before the final sensory reward is activated }\end{array}$ \\
\hline
\end{tabular}

\footnotetext{
${ }^{5}$ The final sensory rewards (e.g. flashing light, sounds, image, etc.) will depend on the technical characteristics of the specific robot and the interaction module.
} 


\section{Objectives:}

\begin{tabular}{|c|c|c|c|c|}
\hline Area & Educational and therapeutic objectives & AUT & SMI & MMR \\
\hline \multirow{2}{*}{ 豙 } & Perceptual functions & & & \\
\hline & - to improve visual perception & $\phi$ & $\phi$ & $\phi$ \\
\hline \multirow{7}{*}{ 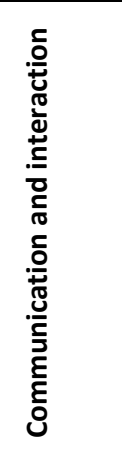 } & $\begin{array}{l}\text { Basic interpersonal interaction } \\
\text { - to improve turn-taking }\end{array}$ & - & - & 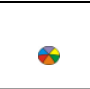 \\
\hline & - to foster taking initiative & $\theta$ & $\theta$ & (2) \\
\hline & - $\quad$ to maximise proximity between peers $\rightarrow$ NO VARIATION 1 & 0 & & $\phi$ \\
\hline & - $\quad$ to improve gaze shift and eye contact with others & 0 & & 0 \\
\hline & - to improve level of response to social cues & $\phi$ & & $\phi$ \\
\hline & - to improve level of response to others & 0 & & $\phi$ \\
\hline & $\begin{array}{l}\text { Particular interpersonal relationships } \\
\text { - to encourage participation with classmates }\end{array}$ & $\theta$ & $\phi$ & $\phi$ \\
\hline \multirow{5}{*}{ 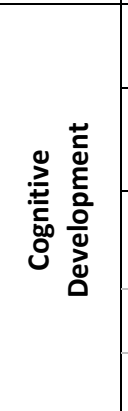 } & $\begin{array}{c}\text { Global intellectual functions } \\
\text { - to improve understanding of cause and effect }\end{array}$ & 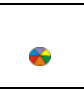 & $0^{6}$ & 0 \\
\hline & $\begin{array}{l}\text { Higher-level cognitive functions } \\
\text { - to improve the control of the wish for or delay of gratification }\end{array}$ & 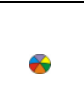 & & - \\
\hline & $\begin{array}{l}\text { Attention } \\
\bullet \quad \text { to improve focusing attention }\end{array}$ & $\phi$ & & $\phi$ \\
\hline & - to improve the ability to maintain attention & 0 & $\phi$ & $\theta$ \\
\hline & - to improve joint attention & 0 & $\phi$ & $\theta$ \\
\hline \multirow{2}{*}{ 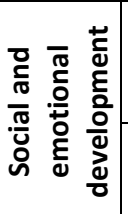 } & $\begin{array}{l}\text { Engagement in play } \\
-\quad \text { to foster shared cooperative play }\end{array}$ & $\theta$ & - & $\phi$ \\
\hline & $\begin{array}{l}\text { Community social and civic life } \\
\text { - to improve the ability to understand and apply play rules }\end{array}$ & $\phi$ & & $\phi$ \\
\hline \multirow{3}{*}{ 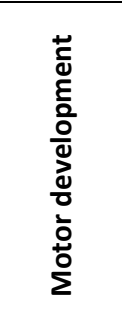 } & $\begin{array}{l}\text { Mobility (body) } \\
\quad \text { to increase gross motor control to improve coordination and } \\
\text { balance }\end{array}$ & & $\phi$ & \\
\hline & $\begin{array}{l}\text { Mobility (fine hand use) } \\
\qquad \quad \text { to improve fine coordinated hand use }\end{array}$ & & $\phi$ & \\
\hline & $\begin{array}{l}\text { Psychomotor functions } \\
\text { - to improve psychomotor control }\end{array}$ & $\phi_{7}^{\phi}$ & $\phi$ & $\phi$ \\
\hline
\end{tabular}

\subsubsection{Scenario IS03 "Imitation"}

The IS03 play scenario is an exercise play with a robot that has moving parts which can be identified as 'body parts' for the child to imitate. It consists of an imitation game where one of

\footnotetext{
${ }^{6}$ Only if children are very young or with a very small experience of action on objects.

${ }^{7}$ If the reward is given specifically to a child with stereotypic behaviour, the scenario can be used to moderate or modify his/her stereotypical behaviour.
} 
the players operates the robot remotely and the other player imitates its movement. The scenario has mainly been developed to be played by children with autism as collaborative play, but it can also be played by children with SMI and MMR.

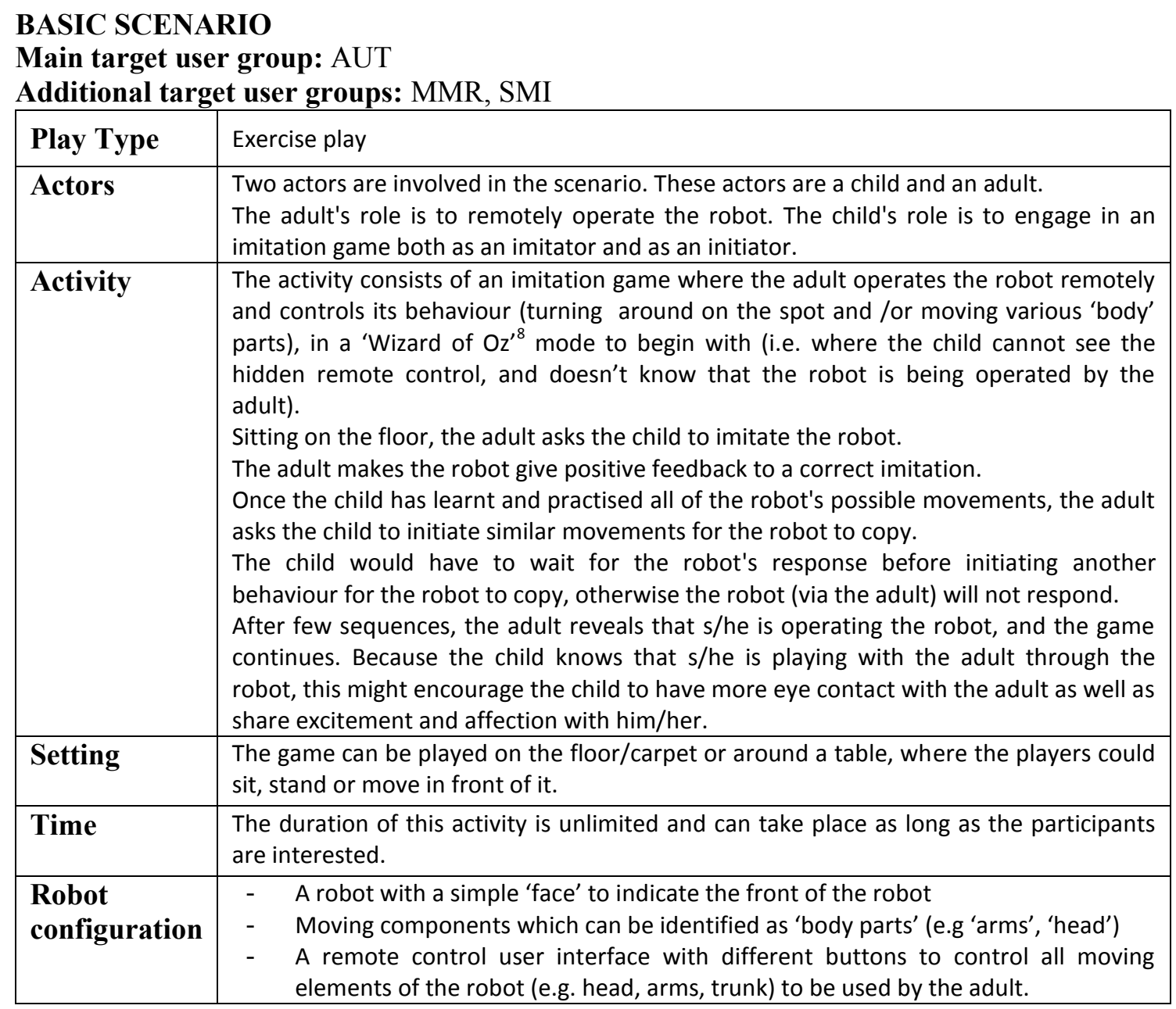

\section{VARIATIONS:}

\section{Variation 1 - I am in control}

\begin{tabular}{|l|l|}
\hline Target group & AUT - MMR - SMI \\
\hline Actors & $\begin{array}{l}\text { In this variation the two players involved in the scenario could be two children or a } \\
\text { child and an adult. }\end{array}$ \\
\hline
\end{tabular}

\footnotetext{
8 The Wizard-of-Oz technique is a widely used evaluation technique in Human-Computer Interaction and, more recently, Human-Robot Interaction research e.g. (Dahlback, Jonsson, and Ahrenberg, 1993). It involves a human who (unknown to the test subjects) is controlling the behaviour of the system, ranging from full tele-operation to partial control of 'higher level' decision-making processes.
} 


\begin{tabular}{|l|l|}
\hline Activity & $\begin{array}{l}\text { The game starts with the child operating the robot remotely. } \\
\text { The other player responds by imitating the robot's movements. } \\
\text { The child that operates the robot needs to check the other player's action and to make } \\
\text { the robot give positive feedback to correct imitation (by pressing the 'global positive } \\
\text { feedback' button). } \\
\text { Only then the child can initiate another robot movement, otherwise the other player } \\
\text { will not respond. }\end{array}$ \\
\hline $\begin{array}{l}\text { Additional } \\
\text { robot } \\
\text { characteristics }\end{array}$ & A remote control to be used by the player. \\
\hline
\end{tabular}

\section{Objectives:}

\begin{tabular}{|c|c|c|c|c|}
\hline Area & Educational and therapeutic objectives & AUT & SMI & MMR \\
\hline 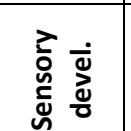 & $\begin{array}{l}\text { Perceptual functions } \\
-\quad \text { to improve body awareness }\end{array}$ & $\theta$ & & - \\
\hline \multirow{5}{*}{ 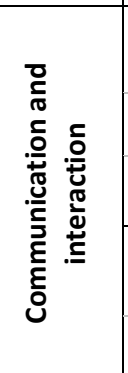 } & $\begin{array}{l}\text { Basic interpersonal interaction } \\
\text { - to improve turn-taking }\end{array}$ & - & 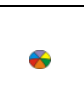 & $\theta$ \\
\hline & - to improve gaze shift and eye contact with others & $\theta$ & & $\phi$ \\
\hline & - to improve level of response to others & 0 & & 0 \\
\hline & $\begin{array}{l}\text { Particular interpersonal relationships } \\
\text { - to foster a therapeutic relationship }\end{array}$ & $\phi$ & & t \\
\hline & - to encourage participation with classmates & $\theta$ & $\phi$ & \\
\hline \multirow{9}{*}{ 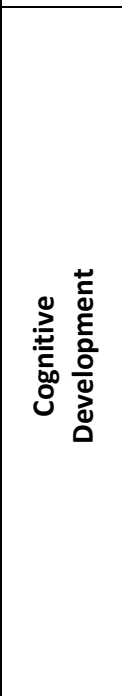 } & $\begin{array}{l}\text { Energy and drive functions } \\
-\quad \text { to improve motivation to act } \rightarrow \text { VARIATION } 1\end{array}$ & $\phi$ & - & \\
\hline & - to feel in control & $\phi$ & $\theta$ & \\
\hline & $\begin{array}{l}\text { Global intellectual functions } \\
\text { - to improve understanding of cause and effect }\end{array}$ & $\phi$ & & \\
\hline & $\begin{array}{l}\text { Copying } \\
\begin{array}{l}\text { - to improve the ability to mirror and imitate simple and complex } \\
\text { movements }\end{array}\end{array}$ & $\theta$ & $\phi$ & - \\
\hline & $\begin{array}{l}\text { Attention } \\
\bullet \quad \text { to improve focusing attention }\end{array}$ & $\phi$ & & $\phi$ \\
\hline & - to improve the ability to maintain attention & $\theta$ & & 0 \\
\hline & - to improve shifting attention & $\phi$ & & $\phi$ \\
\hline & - to improve dividing attention & $\phi$ & & $\phi$ \\
\hline & - to improve joint attention & $\phi$ & & $\phi$ \\
\hline \multirow{3}{*}{ 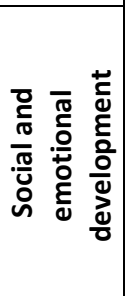 } & $\begin{array}{l}\text { Emotional functions } \\
\text { - to improve self esteem }\end{array}$ & & $\phi$ & $\phi$ \\
\hline & $\begin{array}{l}\text { Experience of self and others } \\
\text { - to improve the sense of self and the awareness of one's own } \\
\text { body and identity }\end{array}$ & $\theta$ & & 0 \\
\hline & $\begin{array}{l}\text { Engagement in play } \\
\text { to foster shared cooperative play }\end{array}$ & $\phi$ & $\theta$ & $\phi$ \\
\hline
\end{tabular}




\begin{tabular}{|c|c|c|c|c|}
\hline Area & Educational and therapeutic objectives & AUT & SMI & MMR \\
\hline & $\begin{array}{l}\text { Community social and civic life } \\
\text { - to improve the ability to understand and apply play rules }\end{array}$ & $\phi$ & & $\phi$ \\
\hline \multirow{6}{*}{ 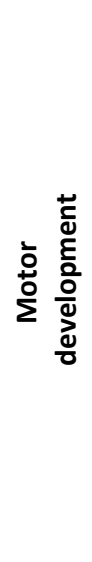 } & $\begin{array}{l}\text { Mobility (body) } \\
\qquad \quad \text { to increase gross motor control }\end{array}$ & & $\theta$ & \\
\hline & $\begin{array}{l}\text { Mobility (fine hand use) } \\
-\quad \text { to improve fine coordinated hand use } \rightarrow \text { VARIATION } 1 \text { (e.g. } \\
\text { using fingers and hands to carry out coordinated actions such as } \\
\text { pressing a button) }\end{array}$ & & $\phi$ & \\
\hline & $\begin{array}{l}\text { Neuromusculoskeletal functions } \\
\text { - to improve control of simple voluntary movement }\end{array}$ & & $\bullet$ & \\
\hline & - to improve coordination of simple movement & & 0 & \\
\hline & $\begin{array}{l}\text { Psychomotor functions } \\
\text { - to improve psychomotor control }\end{array}$ & $\phi$ & 0 & $\phi$ \\
\hline & - to improve organization of psychomotor functions & 0 & $\phi$ & $\theta$ \\
\hline
\end{tabular}

\subsubsection{Scenario IS04 "Make it move"}

The IS04 play scenario is an exercise play with simple rules using a mobile robot where the players can make it move around the room. The scenario has mainly been developed to be played by children with severe motor impairment as a collaborative play, but it can also be played by children with MMR and AUT. Four variations of the basic scenario have been developed.

\section{BASIC SCENARIO}

Main target user group: SMI

Additional target user groups: MMR, AUT

\begin{tabular}{|l|l|}
\hline Play Type & Exercise play, simple game with rules \\
\hline Actors & $\begin{array}{l}\text { Two or more actors are involved in the scenario. These actors could be a child and an } \\
\text { adult, or two or more children. }\end{array}$ \\
\hline Activity & $\begin{array}{l}\text { The game consists of clapping }{ }^{9} \text { in order to make the mobile robot move around the } \\
\text { room. } \\
\text { Sitting on the floor, the child produces a sound by clapping the hands once or by vOCA } \\
\text { (Voice Output Communication Aid. This sound triggers the robot and makes it move } \\
\text { forward for a short distance. } \\
\text { To keep it moving the child has to clap his/her hands again. } \\
\text { To change the direction of the robot the child has to clap his/her hands twice or three } \\
\text { times in order to make it turn left and right respectively. }\end{array}$ \\
\hline
\end{tabular}

\footnotetext{
${ }^{9}$ Clapping or any similar (i.e. short and sharp) acoustic signal like a horn signal, a drumming signal, etc
} 


\begin{tabular}{|c|c|}
\hline & $\begin{array}{l}\text { The game can be played with several participants as a turn-taking game, either with a } \\
\text { simple rule, where each player is responsible for moving the robot to one of the } \\
\text { directions (forward, left, right), or with no rules, where the players simply take turns to } \\
\text { make it move. }\end{array}$ \\
\hline Setting & $\begin{array}{l}\text { The game is played on the floor in a quiet room with a large empty space, to enable the } \\
\text { child and the robot to move around. }\end{array}$ \\
\hline Time & The activity is unlimited and can continue as long as the child is interested. \\
\hline $\begin{array}{l}\text { Robot } \\
\text { configuration }\end{array}$ & 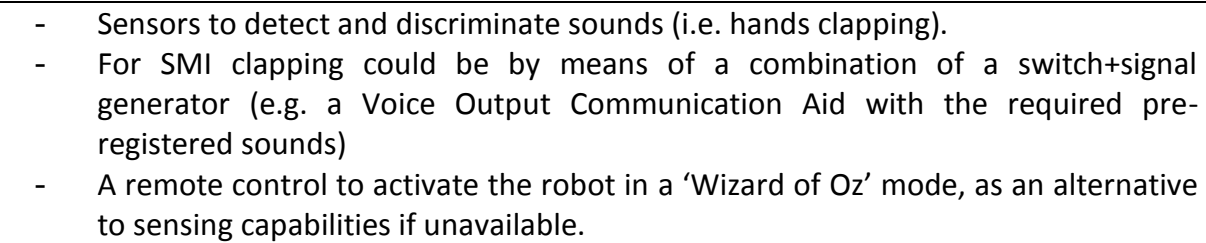 \\
\hline
\end{tabular}

\section{VARIATIONS:}

Variation 1 - Vocal input / Speech sound

\begin{tabular}{|l|l|}
\hline Target group & AUT - MMR - SMI \\
\hline Activity & $\begin{array}{l}\text { In the variation instead of using clapping to make the robot move around the room, the } \\
\text { player can use speech sound. }\end{array}$ \\
\hline $\begin{array}{l}\text { Additional } \\
\text { robot } \\
\text { characteristics. }\end{array}$ & Vocal input: speech sound $^{10}$ \\
\hline
\end{tabular}

\section{Variation 2 - Change speed}

\begin{tabular}{|l|l|}
\hline Target group & AUT - MMR - SMI \\
\hline Activity & $\begin{array}{l}\text { In the variation the robot moves when one of the players claps his/her hands, and it } \\
\text { stops when the player stops clapping. } \\
\text { The robot moves according to the frequencies (time between two claps) of the } \\
\text { clapping (e.g. if the player claps quickly, the robot moves quickly, if the player claps } \\
\text { slowly the robot moves slowly). }\end{array}$ \\
\hline $\begin{array}{l}\text { Additional } \\
\text { robot } \\
\text { characteristics }\end{array}$ & $\begin{array}{l}\text { Identifies frequency of (clapping) signals and changes speed accordingly. } \\
\text { Basic moving patterns (e.g. Bump and Turn) }\end{array}$ \\
\hline
\end{tabular}

\section{Variation 3 - Solitary play}

\begin{tabular}{|l|l|}
\hline Target group & MMR - SMI - AUT \\
\hline Activity & $\begin{array}{l}\text { In this variation the child is playing alone and the adult is there to support and sustain } \\
\text { the activity. }\end{array}$ \\
\hline
\end{tabular}

\section{Variation 4 - Circadian rhythm}

\begin{tabular}{|l|l|}
\hline Target group & MMR - SMI \\
\hline Activity & $\begin{array}{l}\text { Depends on the setting: at the beginning of the activity the robot can be 'lazy' (it } \\
\text { reacts with longer delay), requiring more effort from the player to make it move. As } \\
\text { the game progresses the robot becomes more active, requires less effort from the } \\
\text { player and becomes 'lazy' again at the end of the game. }\end{array}$ \\
\hline
\end{tabular}

\footnotetext{
${ }^{10}$ It is important to highlight that speech is an element of verbal communication, while speech sounds (for example 'baba') and non speech sounds are vocal communication elements. Speech sound is an individual sound unit of speech without concern as to whether or not it is a phoneme of some language. As a result neither vocal articulation (from the children) nor voice recognition (for the robot) are aspects of that variation.
} 


\begin{tabular}{|l|l|}
\hline $\begin{array}{l}\text { Additional } \\
\text { robot } \\
\text { characteristics }\end{array}$ & $\begin{array}{l}\text { The robot has pre-defined rhythms or states such 'lazy' or 'active' (speeds for its } \\
\text { responses - e.g. if the robot is in a 'lazy' state (after lunch) then it reacts not as quickly } \\
\text { as it would in an 'active' state). These slow/'lazy' or 'active' circadian rhythms are not } \\
\text { controlled dynamically during the play but are part of the robot's pre-defined } \\
\text { behaviour as set by the adult according to the child's need. }\end{array}$ \\
\hline
\end{tabular}

Objectives:

\begin{tabular}{|c|c|c|c|c|}
\hline Area & Educational and therapeutic objectives & AUT & SMI & MMR \\
\hline 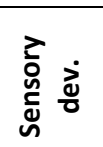 & $\begin{array}{l}\text { Perceptual functions } \\
\text { - to improve visuospatial perception (spatial awareness) }\end{array}$ & $\phi$ & $\phi$ & - \\
\hline \multirow{7}{*}{ 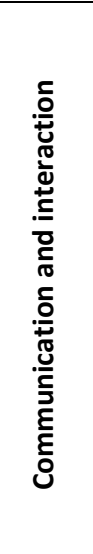 } & $\begin{array}{l}\text { Voice and speech functions } \\
\text { - to improve articulation functions } \rightarrow \text { VARIATION } 1\end{array}$ & $\phi$ & & $\phi$ \\
\hline & $\begin{array}{l}\text { Communicating- Producing - Pretalking } \\
\text { - to improve verbal and preverbal vocalization } \rightarrow \text { VARIATION } 1\end{array}$ & - & - & - \\
\hline & $\begin{array}{l}\text { Communicating - producing - nonverbal messages } \\
\text { - to improve non verbal aspects such as gestures and pointing }\end{array}$ & $\phi$ & & $\phi$ \\
\hline & $\begin{array}{l}\text { Basic interpersonal interaction } \\
\text { - to improve turn-taking }\end{array}$ & $\phi$ & - & - \\
\hline & - to foster taking initiative & $\phi$ & - & $\phi$ \\
\hline & - to improve gaze shift and eye contact with others & & & $\phi$ \\
\hline & - to improve level of response to others & $\phi$ & & $\phi$ \\
\hline \multirow{8}{*}{ 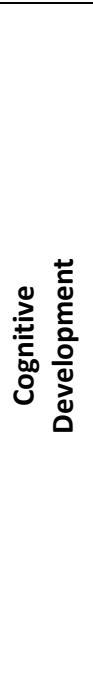 } & $\begin{array}{l}\text { Global intellectual functions } \\
\text { - to improve understanding of cause and effect }\end{array}$ & ๑ & & 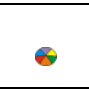 \\
\hline & $\begin{array}{l}\text { Memory functions } \\
-\quad \text { to improve short term memory }\end{array}$ & & $\phi$ & \\
\hline & $\begin{array}{l}\text { Higher-level cognitive functions } \\
-\quad \text { to improve abstraction } \rightarrow \text { VARIATION } 4\end{array}$ & & $\phi$ & \\
\hline & $\begin{array}{l}\text { Attention } \\
\qquad \quad \text { to improve focusing attention }\end{array}$ & $\phi$ & & $\phi$ \\
\hline & - to improve the ability to maintain attention & $\phi$ & $\phi$ & $\phi$ \\
\hline & - to improve joint attention & $\phi$ & $\phi$ & $\phi$ \\
\hline & $\begin{array}{l}\text { Making decisions } \\
\bullet \quad \text { to improve decision-making abilities }\end{array}$ & & & $\phi$ \\
\hline & $\begin{array}{l}\text { Undertaking single/multiple task } \\
\text { - to improve the ability to undertake a single task }\end{array}$ & $\phi$ & & $\phi$ \\
\hline \multirow{6}{*}{ 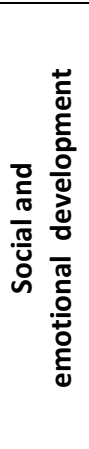 } & $\begin{array}{l}\text { Emotional functions } \\
\bullet \quad \text { to improve self esteem }\end{array}$ & & - & $\phi$ \\
\hline & $\begin{array}{l}\text { Experience of self and others } \\
\text { - to improve sense of agency }\end{array}$ & $\phi$ & $\phi$ & $\phi$ \\
\hline & $\begin{array}{l}\text { Engagement in play } \\
-\quad \text { to foster solitary play } \rightarrow \text { VARIATION } 3\end{array}$ & & $\phi$ & $\phi$ \\
\hline & - to foster parallel play & & - & \\
\hline & - to foster shared cooperative play & $\phi$ & $\bullet$ & $\phi$ \\
\hline & $\begin{array}{l}\text { Community social and civic life } \\
\text { - to improve the ability to understand and apply play rules }\end{array}$ & $\phi$ & & $\phi$ \\
\hline
\end{tabular}




\begin{tabular}{|c|c|c|c|c|}
\hline Area & Educational and therapeutic objectives & AUT & SMI & MMR \\
\hline \multirow{2}{*}{ 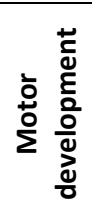 } & $\begin{array}{l}\text { Psychomotor functions } \\
\bullet \quad \text { to improve organization of psychomotor functions }\end{array}$ & $\phi$ & $\phi$ & 0 \\
\hline & $\begin{array}{l}\text { Neuromusculoskeletal functions } \\
\text { - to improve control of simple voluntary movement }\end{array}$ & & $\phi$ & \\
\hline
\end{tabular}

\subsubsection{Scenario ISO5 "Follow me"}

The IS05 play scenario is an exercise play and a simple symbolic play, with a mobile robot that can follow the player moving around the room. The scenario has mainly been developed to be played by children with mild mental retardation as collaborative play, but it can also be played by children with SMI and AUT.

\section{BASIC SCENARIO}

Main target user group: MMR

Additional target user groups: SMI, AUT

\begin{tabular}{|l|l|}
\hline Play Type & Exercise play, simple symbolic play \\
\hline Actors & Two children are involved in the game. \\
\hline Activity & $\begin{array}{l}\text { The game consists of playing with a mobile robot that can follow a player and stay in } \\
\text { place if told to do so. } \\
\text { The robot can be guided in 'follow-me' mode from a child to another child. } \\
\text { The players are in a room, located some distance from each other. } \\
\text { The game starts when the first player activates the 'follow-me' mode (e.g. by clapping } \\
\text { or pressing a button). The robot starts to move, searching for a child. When it finds a } \\
\text { child it follows him/her within a predefined distance (e.g. 50 cm). If the child stops, the } \\
\text { robot stops too. The child can also give a signal to the robot to suspend or reactivate } \\
\text { the 'follow-me' mode. } \\
\text { When the child and the following robot reach the second player, and the robot is closer } \\
\text { to the second player, it starts to follow the second player. }\end{array}$ \\
\hline Thime & $\begin{array}{l}\text { This scenario is performed on the floor in any area with sufficient space, to allow the } \\
\text { robot and the children to move. Ideally the activity can be spread over more rooms. }\end{array}$ \\
\hline $\begin{array}{l}\text { Robot } \\
\text { configuration }\end{array}$ & $\begin{array}{l}\text { The gactivity is unlimited and can continue as long as the child is interested. } \\
\text { wait at a specific location by using a "stay where you are" signal and might be re- } \\
\text { activated later. }\end{array}$ \\
\hline$-\quad \begin{array}{l}\text { To activate or deactivate the 'follow-me' mode: sound recognition system } \\
\text { (clapping) or button on the remote control. } \\
\text { Sensors to detect the child's movement } \\
\text { Following distance: e.g. } 50 \text { cm (it is important to be able to adjust the distance } \\
\text { and proximity to child's preferences). } \\
\text { to sensing capabilities if unavailable. }\end{array}$ \\
\hline
\end{tabular}




\section{VARIATIONS:}

Variation 1 - Move together

\begin{tabular}{|l|l|}
\hline Target group & AUT - MMR - SMI \\
\hline Activity & $\begin{array}{l}\text { In the basic scenario the robot is guided from one player to the other one. } \\
\text { A variation of the activity can be a cooperative game where the two children have to } \\
\text { move together in order to let the robot move. In this variation the robot moves only if } \\
\text { both children are moving together at the same time and in the same direction and it } \\
\text { stops when one of the children is not moving or the children start to move in two } \\
\text { different directions }\end{array}$ \\
\hline $\begin{array}{l}\text { Additional } \\
\text { robot } \\
\text { characteristics }\end{array}$ & $\begin{array}{l}- \text { Sensors to detect children's movement } \\
\text { - }\end{array}$ \\
\hline
\end{tabular}

Variation 2-Control the robot movements

\begin{tabular}{|l|l|}
\hline Target group & AUT - SMI - MMR \\
\hline Activity & $\begin{array}{l}\text { One child is remotely controlling the robot's movements. The other child is either } \\
\text { following the robot or being followed by the robot. }\end{array}$ \\
\hline $\begin{array}{l}\text { Additional } \\
\text { robot } \\
\text { characteristics }\end{array}$ & Remote control to control the robot's movements \\
\hline
\end{tabular}

Variation 3 - Follow the robot
\begin{tabular}{|l|l|}
\hline Target group & AUT - SMI - MMR \\
\hline Activity & $\begin{array}{l}\text { In this variation the child is the one that follows the robot. } \\
\text { The robot starts to move around (simply avoiding obstacles) and at the same time it } \\
\text { detects if a child is following it (i.e. a child is present within a pre-defined distance, just } \\
\text { outside the obstacle avoidance zone e.g. in an area between } 0.5 \text { and } 1.5 \mathrm{~m} \text { ). Once } \\
\text { detecting a child behind it, the robot will continue moving around and avoiding } \\
\text { obstacles as long as it can detect the child (i.e., the child is following the robot). The } \\
\text { robot will adapt to the child's speed. }\end{array}$ \\
\hline $\begin{array}{l}\text { Additional } \\
\text { robot } \\
\text { characteristics }\end{array}$ & Basic moving patterns (e.g. Bump and Turn) \\
\hline
\end{tabular}

\section{Objectives:}

\begin{tabular}{|c|c|c|c|c|}
\hline Area & Educational and therapeutic objectives & AUT & SMI & MMR \\
\hline 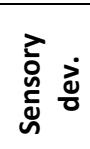 & $\begin{array}{l}\text { Perceptual functions } \\
\bullet \quad \text { to improve visuospatial perception (spatial awareness) }\end{array}$ & - & $\phi$ & $\theta$ \\
\hline \multirow{3}{*}{ 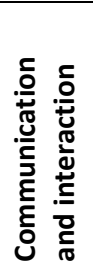 } & $\begin{array}{l}\text { Communicating- Producing - Pretalking } \\
\text { - to improve verbal and preverbal vocalization }\end{array}$ & & $\phi$ & \\
\hline & $\begin{array}{l}\text { Communicating - producing - no nverbal messages } \\
\text { - to improve non verbal aspects such as gestures and pointing }\end{array}$ & $\phi$ & $\theta$ & - \\
\hline & $\begin{array}{l}\text { Basic interpersonal interaction } \\
\qquad \quad \text { to improve turn-taking } \rightarrow \text { NO VARIATION } 1\end{array}$ & $\phi$ & $\phi$ & $\phi$ \\
\hline
\end{tabular}




\begin{tabular}{|c|c|c|c|c|}
\hline Area & Educational and therapeutic objectives & AUT & SMI & MMR \\
\hline \multirow{10}{*}{ 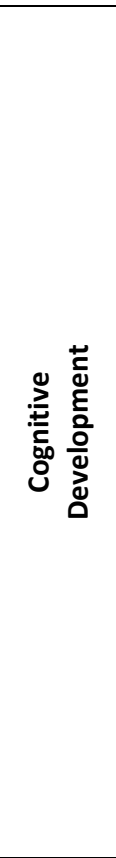 } & $\begin{array}{l}\text { Energy and drive functions } \\
\text { to feel in control }\end{array}$ & $\epsilon$ & $\phi$ & $\phi$ \\
\hline & $\begin{array}{c}\text { Global intellectual functions } \\
\text { - to improve understanding of cause and effect }\end{array}$ & $\phi$ & & \\
\hline & $\begin{array}{l}\text { Higher-level cognitive functions } \\
\text { - to improve organization and planning }\end{array}$ & & $\phi$ & $€$ \\
\hline & $\begin{array}{l}\text { Copying } \\
\text { to improve the ability to mirror and imitate simple and complex } \\
\text { movements } \rightarrow \text { VARIATION } 1\end{array}$ & $\phi$ & 0 & \\
\hline & $\begin{array}{l}\text { Attention } \\
-\quad \text { to improve focusing attention }\end{array}$ & $\phi$ & $\phi$ & $\phi$ \\
\hline & $\begin{array}{l}\text { - to improve the capacity to attend to the human touch, face and } \\
\text { voice }\end{array}$ & & & \\
\hline & - to improve the ability to maintain attention & $\phi$ & $\phi$ & $\phi$ \\
\hline & - to improve shifting attention & $\phi$ & $\phi$ & $\phi$ \\
\hline & - to improve joint attention & $\theta$ & $\phi$ & 0 \\
\hline & $\begin{array}{c}\text { Thinking } \\
\bullet \quad \text { to foster pretending }\end{array}$ & & $\phi$ & $\phi$ \\
\hline \multirow{2}{*}{ 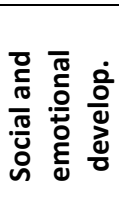 } & $\begin{array}{l}\text { Engagement in play } \\
-\quad \text { to foster shared cooperative play }\end{array}$ & $\theta$ & 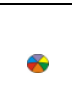 & $\bullet$ \\
\hline & $\begin{array}{l}\text { Community social and civic life } \\
\text { to improve the ability to understand and apply play rules } \\
\rightarrow \text { VARIATION } 1\end{array}$ & $\phi$ & $\phi$ & $\phi$ \\
\hline \multirow{6}{*}{ 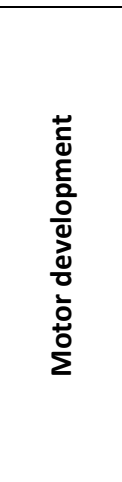 } & $\begin{array}{l}\text { Mobility (body) } \\
\qquad \quad \text { to improve coordination and balance }\end{array}$ & & 2 & \\
\hline & $\begin{array}{l}\text { - to improve the capacity to walk and move around using } \\
\text { equipment }\end{array}$ & & - & \\
\hline & $\begin{array}{l}\text { Mobility (fine hand use) } \\
\qquad \quad \text { to improve fine coordinated hand use } \rightarrow \text { VARIATION } 2\end{array}$ & & $\phi$ & \\
\hline & $\begin{array}{l}\text { Neuromusculoskeletal functions } \\
\text { - to improve control of simple voluntary movement }\end{array}$ & & $\phi$ & \\
\hline & $\begin{array}{l}\text { Psychomotor functions } \\
\text { - to improve psychomotor control }\end{array}$ & $\phi$ & $\theta$ & $\phi$ \\
\hline & - to improve organization of psychomotor functions & & 0 & $\theta$ \\
\hline
\end{tabular}

\subsubsection{Scenario IS06 "Dance with me"}

The IS06 play scenario is an exercise play with simple rules with a mobile robot that can move to the rhythm of a pre-recorded piece of music in a pre-programmed set of 'steps', that the child can copy, in order to 'dance together'. The scenario has mainly been developed to be played by children with severe motor impairments as solitary play, but it can also be played by children with MMR. 


\section{BASIC SCENARIO}

Main target user group: SMI

Additional target user groups: MMR

\begin{tabular}{|l|l|}
\hline Play Type & Exercise play, game with rules \\
\hline Actors & $\begin{array}{l}\text { A child is involved in the game. } \\
\text { The adult (a therapist or a teacher) has only a supportive and rewarding role. }\end{array}$ \\
\hline \multirow{2}{*}{ Activity } & $\begin{array}{l}\text { In this game a child makes the robot 'dance' - i.e. move to the rhythm of a pre- } \\
\text { recorded piece of music in a pre-programmed set of 'steps', that s/he can copy, in order } \\
\text { to 'dance together'. } \\
\text { The robot is placed in the central position on a 3x3 carpet (chess-type). The activity } \\
\text { starts when the child triggers the robot to play the child's favourite songs or music and } \\
\text { the robot starts to 'dance' a simple pre-defined choreography. The robot does } 5 \text { or } 6 \\
\text { moves on the carpet according to the beats of the music. By moving on the carpet the } \\
\text { robot gives the child visual feedback of its movements. } \\
\text { At the end of the 'dance' the robot uses a pre-recorded message to invite the child to } \\
\text { do the same 'dance' (set of movements) and the child will copy the robot's moves on } \\
\text { his/her carpet, either after the robot or simultaneously with it. } \\
\text { The adult via remote control can give positive feedback when the child copies the } \\
\text { moves correctly. }\end{array}$ \\
\hline Setting & $\begin{array}{l}\text { The game is played on the floor, in a room where there should be enough free space for } \\
\text { placing the } 2 \text { carpets (3x3 chess-type). }\end{array}$ \\
\hline Cobot \\
configuration & $\begin{array}{l}\text { The basic phase can repeat itself many times, thus the duration of the activity is } \\
\text { unlimited and can take place as long as the player is interested. }\end{array}$ \\
$-\begin{array}{l}\text { - Music reproduction } \\
\text { pace ('steps'), each set matched to the bit of a different pre-recorded piece of music. } \\
- \text { Remote control for the adult to give feedback if the child imitates the 'dance' correctly } \\
-2 \text { carpets (3x3 chess-type) } \\
- \text { Sensory display during the dance (e.g. projections, lights etc) } \\
- \text { A remote control to activate the robot in a 'Wizard of Oz' mode, as an alternative to } \\
\text { the pre-set dance choreographed movements. }\end{array}$ \\
\hline
\end{tabular}

\section{VARIATIONS:}

\section{Variation 1 - Positions}

\begin{tabular}{|l|l|}
\hline Target group & MMR - SMI \\
\hline Activity & $\begin{array}{l}\text { In this variation the child is the one who composes the dance (as opposed to the basic } \\
\text { scenario where the robot is moving to pre-programmed choreography). The child selects } \\
\text { on an input device a sequence of different positions for the robot to move to } \\
\text { When the child finishes 'teaching' the robot the set of the dance moves, the robot can } \\
\text { reproduce the sequence of movements (according to pre-defined rhythms/speed related } \\
\text { to the choice of the pre-recorded music and they can dance together. }\end{array}$ \\
\hline $\begin{array}{l}\text { Additional } \\
\text { robot } \\
\text { characteristics }\end{array}$ & $\begin{array}{l}\text { - } \\
\text { Pre-programmed music with a given number of 'beats'. }\end{array}$ \\
\hline
\end{tabular}

${ }^{11}$ The "taught" choreography is then automatically segmented into basic moves (i.e. turning and moving to the next neighbouring field). The segments then are synchronized with a pre-defined time-line according to the rhythm/speed of the music and executed accordingly. 
Objectives:

\begin{tabular}{|c|c|c|c|c|}
\hline Area & Educational and therapeutic objectives & AUT & SMI & MMR \\
\hline 竞 & $\begin{array}{l}\text { Perceptual functions } \\
\qquad \quad \text { to improve visuospatial perception (spatial awareness) }\end{array}$ & & $\phi$ & $\theta$ \\
\hline \multirow{14}{*}{ 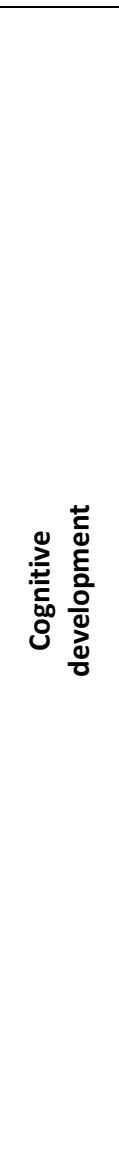 } & $\begin{array}{c}\text { Global intellectual functions } \\
\text { • to improve understanding of cause and effect }\end{array}$ & & & \\
\hline & $\begin{array}{l}\text { Memory functions } \\
\bullet \quad \text { to improve short term memory }\end{array}$ & & * & \\
\hline & $\begin{array}{c}\text { Higher-level cognitive functions } \\
\text { - to improve abstraction }\end{array}$ & & $\phi$ & $\theta$ \\
\hline & - to improve organization and planning & & $\phi$ & $\phi$ \\
\hline & $\begin{array}{l}\text { Copying } \\
\qquad \quad \text { to improve the ability to mirror and imitate simple and complex } \\
\text { movements }\end{array}$ & & $\phi$ & $\theta$ \\
\hline & $\begin{array}{l}\text { Attention } \\
-\quad \text { to improve focusing attention }\end{array}$ & & $\phi$ & $\phi$ \\
\hline & - to improve the capacity to attend to changes in the environment & & $\phi$ & $\phi$ \\
\hline & - to improve the ability to maintain attention & & - & $\theta$ \\
\hline & - to improve shifting attention & & $\theta$ & - \\
\hline & - to improve dividing attention & & $\theta$ & - \\
\hline & $\begin{array}{l}\text { Solving problems } \\
-\quad \text { to improve the ability to solve problems }\end{array}$ & & $\phi$ & $\phi$ \\
\hline & $\begin{array}{c}\text { Thinking } \\
\bullet \quad \text { to foster hypothesizing }\end{array}$ & & & $\phi$ \\
\hline & $\begin{array}{l}\text { Making decisions } \\
\bullet \quad \text { to improve decision-making abilities } \rightarrow \text { VARIATION } 1\end{array}$ & & - & - \\
\hline & $\begin{array}{l}\text { Undertaking single/multiple task } \\
\text { - to improve the ability to undertake a complex task }\end{array}$ & & 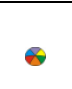 & * \\
\hline \multirow{4}{*}{ 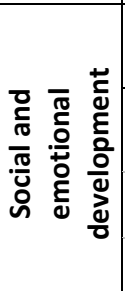 } & $\begin{array}{l}\text { Engagement in play } \\
\text { - to foster solitary play }\end{array}$ & & $\phi$ & $\phi$ \\
\hline & $\begin{array}{l}\text { Community social and civic life } \\
\text { - to improve the ability to understand and apply play rules }\end{array}$ & & 8 & $\bullet$ \\
\hline & - to improve the ability to change play rules & & $\phi$ & $\phi$ \\
\hline & - to improve the ability to negotiate play rules & & $\phi$ & \\
\hline \multirow{4}{*}{ 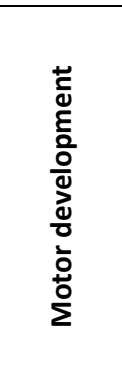 } & $\begin{array}{l}\text { Mobility (body) } \\
-\quad \text { to increase gross motor control }\end{array}$ & & $\phi$ & \\
\hline & $\begin{array}{l}\text { - to improve the capacity to walk and move around using } \\
\text { equipment }\end{array}$ & & $\theta$ & \\
\hline & $\begin{array}{l}\text { Neuromusculoskeletal functions } \\
\text { - to improve control of simple voluntary movement }\end{array}$ & & $\phi$ & \\
\hline & $\begin{array}{l}\text { Psychomotor functions } \\
\text { - to improve organization of psychomotor functions }\end{array}$ & & $\theta$ & $\phi$ \\
\hline
\end{tabular}




\subsubsection{Scenario IS07 "Build the tower"}

The IS07 play scenario is an assembly play with simple rules. A mobile robot with simple 'arms' or other gripping capabilities can help the child to build a tower out of cubes. The scenario has mainly been developed to be played as solitary play by SMI children, but it can also be played by children with MMR.

\section{BASIC SCENARIO}

Main target user group: SMI

Additional target user groups: MMR

\begin{tabular}{|c|c|}
\hline Play Type & Assembly play \\
\hline Actors & A child is involved in the game. \\
\hline Activity & $\begin{array}{l}\text { With the help of the robot the child is able to build a tower out of cubes. } \\
\text { The cubes are lying on the floor and are picked up by the robot randomly (e.g. the cube } \\
\text { that has been detected first by the robot is taken). After picking up the cube the robot } \\
\text { moves back to the starting position (i.e. the position of the tower) and adds the cube. } \\
\text { The play continues until all the cubes are used for the tower. } \\
\text { When the construction is over, the robot can destroy the tower at the child's whim. }\end{array}$ \\
\hline Setting & The game is played on the floor. \\
\hline Time & $\begin{array}{l}\text { The basic phase can repeat itself many times, thus the duration of the activity is } \\
\text { unlimited and can take place as long as the player is are interested. }\end{array}$ \\
\hline $\begin{array}{l}\text { Robot } \\
\text { configuration }\end{array}$ & $\begin{array}{l}\text { - } \\
\text { - } \quad \text { Program execution in automatic mode or stepwise (triggered by button) } \\
\text { - } \quad \text { Gripper to pick up the cube (maybe with sensors detecting presence of cube) } \\
\text { - } \quad \text { One/two arms able to lift up the gripped cube sufficiently (cf. defined maximum } \\
\text { height of the tower) } \\
\text { - } \quad \text { Self-localisation (and sensors) to enable moving back to cube position } \\
\text { - } \quad \text { sensory system to detect and navigate to the cubes } \\
\text { - } \quad \text { Size of the tower: about } 70 \mathrm{~cm} \text {. (i.e. from } 5 \text { to } 7 \text { cubes with cube size } 10 / 15 \mathrm{~cm} \\
\text { - } \quad \text { To activate the building/destroy mode: sound recognition system }{ }^{12} \text { or button on } \\
\text { - } \quad \text { A remote control to activate the robot in a 'Wizard of } O z^{\prime} \text { mode, as an alternative to } \\
\text { sensing capabilities if unavailable. }\end{array}$ \\
\hline
\end{tabular}

\section{VARIATIONS:}

Variation 1 - Next colour

\begin{tabular}{|c|c|}
\hline Target group & MMR - SMI \\
\hline Activity & $\begin{array}{l}\text { If a set of coloured cubes is used, the child could choose the colour of the next cube } \\
\text { with the help of a remote control. }\end{array}$ \\
\hline $\begin{array}{l}\text { Additional } \\
\text { robot } \\
\text { characteristics }\end{array}$ & $\begin{array}{l}\text { - } \quad \text { Remote control to choose the colour of the next cube } \\
\text { - Special colours for the cubes; maximum of } 3 \text { different colours (e.g. neon pink, } \\
\text { neon yellow, neon green). The adult will make sure that the colours of the cubes } \\
\text { are not around in the environment. }\end{array}$ \\
\hline
\end{tabular}

\footnotetext{
${ }^{12}$ Simple sound recognition system already available on the market.
} 
Variations 2 - Remote controls and sub-functions

\begin{tabular}{|l|l|}
\hline Target group & MMR - SMI \\
\hline Actors & Two children. \\
\hline Activity & $\begin{array}{l}\text { In this variation the robot's actions are divided into several high level sub- } \\
\text { functions/instructions (e.g. 'fetch a cube', 'put the cube on the tower'). } \\
\text { Each child controls one instruction at a time, via a remote control. }\end{array}$ \\
\hline $\begin{array}{l}\text { Additional } \\
\text { robot } \\
\text { characteristics }\end{array}$ & Two remote controls \\
\hline
\end{tabular}

\section{Objectives:}

\begin{tabular}{|c|c|c|c|c|}
\hline Area & Educational and therapeutic objectives & AUT & SMI & MMR \\
\hline 突 & $\begin{array}{l}\text { Perceptual functions } \\
\qquad \quad \text { to improve visuospatial perception (spatial awareness) }\end{array}$ & & $\phi$ & 0 \\
\hline \multirow{14}{*}{ 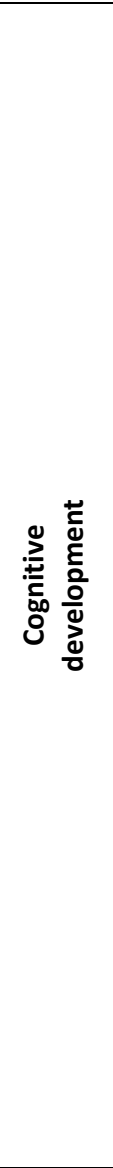 } & $\begin{array}{l}\text { Global intellectual functions } \\
\text { - to improve understanding of cause and effect }\end{array}$ & & & $\phi$ \\
\hline & $\begin{array}{l}\text { Memory functions } \\
\bullet \quad \text { to improve short term memory }\end{array}$ & & $\theta$ & \\
\hline & $\begin{array}{l}\text { Higher-level cognitive functions } \\
\text { - to improve abstraction }\end{array}$ & & $\phi$ & * \\
\hline & - to improve organization and planning & & $\phi$ & $\phi$ \\
\hline & $\begin{array}{l}\text { Copying } \\
\text { - to improve the ability to mirror and imitate simple and complex } \\
\text { movements }\end{array}$ & & $\phi$ & $\theta$ \\
\hline & $\begin{array}{l}\text { Attention } \\
\bullet \quad \text { to improve focusing attention }\end{array}$ & & $\phi$ & $\phi$ \\
\hline & - to improve the capacity to react to changes in the environment & & $\phi$ & $\phi$ \\
\hline & - to improve the ability to maintain attention & & $\theta$ & $\theta$ \\
\hline & - to improve shifting attention & & $\theta$ & - \\
\hline & - to improve dividing attention & & $\theta$ & $\theta$ \\
\hline & $\begin{array}{l}\text { Solving problems } \\
\text { - to improve the ability to solve problems }\end{array}$ & & $\phi$ & $\phi$ \\
\hline & $\begin{array}{l}\text { Thinking } \\
\bullet \quad \text { to foster hypothesizing }\end{array}$ & & & $\phi$ \\
\hline & $\begin{array}{l}\text { Making decisions } \\
\qquad \quad \text { to improve decision-making abilities } \rightarrow \text { VARIATION } 1\end{array}$ & & - & 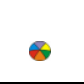 \\
\hline & $\begin{array}{l}\text { Undertaking single/multiple task } \\
\text { - to improve the ability to undertake a complex task }\end{array}$ & & 0 & 0 \\
\hline \multirow{4}{*}{ 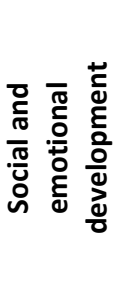 } & $\begin{array}{l}\text { Engagement in play } \\
\text { - to foster solitary play }\end{array}$ & & $\phi$ & $\phi$ \\
\hline & $\begin{array}{l}\text { Community social and civic life } \\
\text { - to improve the ability to understand and apply play rules }\end{array}$ & & $\theta$ & 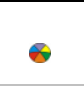 \\
\hline & - to improve the ability to change play rules & & $\phi$ & $\phi$ \\
\hline & - to improve the ability to negotiate play rules & & $\phi$ & \\
\hline
\end{tabular}




\begin{tabular}{|c|c|c|c|c|}
\hline Area & Educational and therapeutic objectives & AUT & SMI & MMR \\
\hline \multirow{4}{*}{ 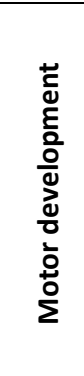 } & $\begin{array}{l}\text { Mobility (body) } \\
-\quad \text { to increase gross motor control }\end{array}$ & & $\phi$ & \\
\hline & $\begin{array}{l}\text { - to improve the capacity to walk and move around using } \\
\text { equipment }\end{array}$ & & - & \\
\hline & $\begin{array}{l}\text { Neuromusculoskeletal functions } \\
\text { - to improve control of simple voluntary movement }\end{array}$ & & $\phi$ & \\
\hline & $\begin{array}{l}\text { Psychomotor functions } \\
\text { - to improve organization of psychomotor functions }\end{array}$ & & $\theta$ & $\phi$ \\
\hline
\end{tabular}

\subsubsection{Scenario IS08 "Bring me the ball"}

The IS08 play scenario is an exercise play with a mobile robot. The game consists of throwing and fetching a ball. The scenario has mainly been developed to be played by children with severe motor impairments as collaborative play, but it can also be played by children with MMR and SMI.

\section{BASIC SCENARIO}

Main target user group: SMI

Additional target user groups: MMR - AUT

\begin{tabular}{|l|l|}
\hline Play Type & Exercise play \\
\hline Actors & $\begin{array}{l}\text { Two children are involved in the game. } \\
\text { One player is throwing the ball, and the other is taking control of the robot. }\end{array}$ \\
\hline Activity & $\begin{array}{l}\text { The game consists of throwing and fetching a ball. } \\
\text { One player has a coloured ball, and the other has a remote control. } \\
\text { The game starts when the child with the ball throws, pushes or rolls it. Then the other } \\
\text { child takes over the job of controlling the robot. } \\
\text { With the help of a special remote control, s/he moves the robot to the ball, lets the } \\
\text { robot pick up the ball, lets the robot bring it to the starting point and release it. These } \\
\text { functions are performed in a semi-automatic mode (the child has just to select different } \\
\text { robot behaviours, such as 'find the ball', 'pick up the ball', and 'bring it to the other } \\
\text { child') or stepwise in a pre-defined sequence. } \\
\text { The robot could give sensory feedback when moving (e.g. a light) and when it performs } \\
\text { the different tasks (e.g. when it picks up the ball, it could emit a sound). } \\
\text { Afterward the whole sequence can be repeated and the players can swap roles; the } \\
\text { player that throws the ball can now take over the job of controlling the robot. }\end{array}$ \\
\hline Setting & $\begin{array}{l}\text { The game is played on the floor, in a room where there should be plenty of uncluttered } \\
\text { floor space. }\end{array}$ \\
\hline Time & $\begin{array}{l}\text { The game is made up of a short sequence of actions. The basic phase can repeat itself } \\
\text { many times, thus the duration of the activity is unlimited and can continue as long as } \\
\text { the players are interested. }\end{array}$ \\
\hline configuration & $\begin{array}{l}\text { Mobile robot } \\
\text { Programme execution in semi-automatic mode }\end{array}$ \\
\hline
\end{tabular}




\begin{tabular}{|l|cl|}
\hline & - & Remote control for triggering/selecting next step. \\
- & Sensor(s) to detect a ball (the ball itself needs to be brightly coloured; not too \\
& heavy; easy to grasp e.g. made of spongy rubber) \\
- & Self-localisation to return to starting position \\
- & Sensory feedback during the different actions (e.g. sound and/or light effects) \\
- & Gripper to pick up a small soft ball \\
- & One/two arms to lift a ball.
\end{tabular}

\section{VARIATIONS:}

Variation 1 - Solitary play

\begin{tabular}{|l|l|}
\hline Target group & MMR - SMI - AUT \\
\hline Actors & $\begin{array}{l}\text { One child is involved in the scenario. The robot is interacting with the child } \\
\text { autonomously (the child throws the ball - the robot brings the ball back to the starting } \\
\text { point). }\end{array}$ \\
\hline Activity & $\begin{array}{l}\text { When the child is playing alone with the robot s/he learns to throw or push the ball and } \\
\text { to watch it move (sensing moving objects). } \\
\text { Then the robot runs in automatic mode, and is able to find and pick up the ball and } \\
\text { bring it back to the starting point, thus offering it for a new start of the game. }\end{array}$ \\
\hline $\begin{array}{l}\text { Additional } \\
\text { robot } \\
\text { characteristics }\end{array}$ & $\begin{array}{l}-\quad \text { Programme execution in automatic mode } \\
\text { him/her }\end{array}$ \\
\hline
\end{tabular}

\section{Objectives:}

\begin{tabular}{|c|c|c|c|c|}
\hline Area & Educational and therapeutic objectives & AUT & SMI & MMR \\
\hline 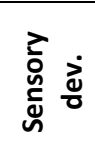 & $\begin{array}{l}\text { Perceptual functions } \\
\qquad \quad \text { to improve visuospatial perception (spatial awareness) }\end{array}$ & & $\phi$ & 0 \\
\hline \multirow{12}{*}{ 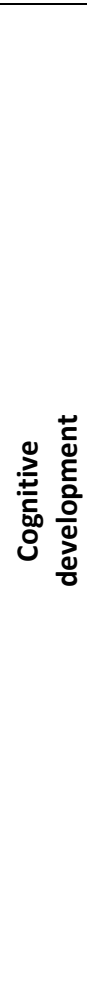 } & $\begin{array}{l}\text { Global intellectual functions } \\
\text { - to improve understanding of cause and effect }\end{array}$ & & & $\phi$ \\
\hline & $\begin{array}{l}\text { Memory functions } \\
\qquad \quad \text { to improve short term memory }\end{array}$ & & - & \\
\hline & $\begin{array}{l}\text { Higher-level cognitive functions } \\
\text { - to improve abstraction }\end{array}$ & & $\phi$ & 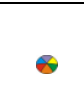 \\
\hline & - to improve organization and planning & & $\phi$ & $\phi$ \\
\hline & $\begin{array}{l}\text { Copying } \\
\text { to improve the ability to mirror and imitate simple and complex } \\
\text { movements }\end{array}$ & & $\phi$ & $\theta$ \\
\hline & $\begin{array}{l}\text { Attention } \\
-\quad \text { to improve focusing attention }\end{array}$ & & $\phi$ & $\phi$ \\
\hline & - to improve the capacity to attend to changes in the environment & & $\phi$ & $\phi$ \\
\hline & - to improve the ability to maintain attention & & $\theta$ & 0 \\
\hline & - to improve shifting attention & & $\theta$ & $\theta$ \\
\hline & - to improve dividing attention & & - & 0 \\
\hline & $\begin{array}{l}\text { Solving problems } \\
-\quad \text { to improve the ability to solve problems }\end{array}$ & & $\phi$ & $\phi$ \\
\hline & Thinking & & & $\phi$ \\
\hline
\end{tabular}




\begin{tabular}{|c|c|c|c|c|}
\hline Area & Educational and therapeutic objectives & AUT & SMI & MMR \\
\hline & $\begin{array}{l}\text { Making decisions } \\
\bullet \quad \text { to improve decision-making abilities } \rightarrow \text { VARIATION } 1\end{array}$ & & - & - \\
\hline & $\begin{array}{l}\text { Undertaking single/multiple task } \\
\text { - to improve the ability to undertake a complex task }\end{array}$ & & 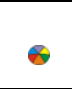 & - \\
\hline \multirow{4}{*}{ 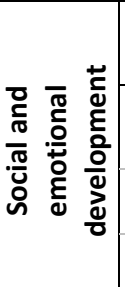 } & $\begin{array}{l}\text { Engagement in play } \\
\qquad \quad \text { to foster solitary play }\end{array}$ & & $\phi$ & $\phi$ \\
\hline & $\begin{array}{l}\text { Community social and civic life } \\
\text { - to improve the ability to understand and apply play rules }\end{array}$ & & - & - \\
\hline & - to improve the ability to change play rules & & $\phi$ & $\phi$ \\
\hline & - to improve the ability to negotiate play rules & & $\phi$ & \\
\hline \multirow{4}{*}{ 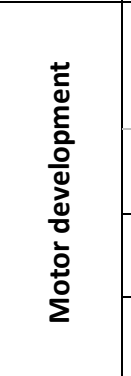 } & $\begin{array}{l}\text { Mobility (body) } \\
\qquad \quad \text { to increase gross motor control }\end{array}$ & & $\phi$ & \\
\hline & $\begin{array}{l}\text { - to improve the capacity to walk and move around using } \\
\text { equipment }\end{array}$ & & - & \\
\hline & $\begin{array}{l}\text { Neuromusculoskeletal functions } \\
\text { - to improve control of simple voluntary movement }\end{array}$ & & $\phi$ & \\
\hline & $\begin{array}{l}\text { Psychomotor functions } \\
\bullet \quad \text { to improve organization of psychomotor functions }\end{array}$ & & - & $\phi$ \\
\hline
\end{tabular}

\subsubsection{Scenario IS09 "Get in contact"}

The IS09 play scenario is an exercise and simple symbolic play where the children explore the robot. The scenario has mainly been developed to be played by children with MMR as a collaborative play, but it can also be played by children with SMI and AUT.

Main target user group: MMR

Additional target user groups: SMI, AUT

\begin{tabular}{|l|l|}
\hline Play Type & Exercise play, simple symbolic play \\
\hline Actors & $\begin{array}{l}\text { There can be one or more players. } \\
\text { The adult has a supportive role. S/he mediates the activity and controls the behaviour } \\
\text { of the robot. }\end{array}$ \\
\hline
\end{tabular}




\begin{tabular}{|c|c|}
\hline Activity & $\begin{array}{l}\text { The adult can dynamically select the robot's behaviour from pre-defined behavioural } \\
\text { patterns throughout the activity. Each behavioural pattern is characterized by a certain } \\
\text { configuration of robot movement, colours, patterns and shape transformation. } \\
\text { At the beginning the adult selects the behavioural pattern expressing a 'feeling of fear'. } \\
\text { The robot does not approach the child and tries to maintain a pre-defined ('safe') } \\
\text { distance from him/her. So when the child tries to approach the robot, it retreats and } \\
\text { changes its appearance to 'fear appearance' (e.g. its colour gets darker, its skin gets } \\
\text { rough). If the robot cannot move back because of an obstacle (wall, other children) s/he } \\
\text { still continues changing its appearance to the 'fear appearance'. Such pattern creates a } \\
\text { context that encourages the child to interpret the robot's behaviour and then change } \\
\text { his/her approach/behaviour towards the robot accordingly (e.g. to approach the robot } \\
\text { slowly). } \\
\text { When the child gently approaches the robot, the adult modifies the behavioural pattern } \\
\text { into 'communicative' mode: the robot now approaches the child, trying to maintain a } \\
\text { short pre-defined distance and shows warm colours in order to invite the child to a } \\
\text { more intimate interaction. } \\
\text { The adult can now select a tactile exploration mode. In this mode, the robot is not } \\
\text { moving but as it is positioned next to the child, the child may touch and explore the } \\
\text { robot's surface. The robot responds by vibrating as if it were purring and getting } \\
\text { smoother and smoother. }\end{array}$ \\
\hline Setting & The game is played on the floor. \\
\hline Time & The activity is unlimited and can continue as long as the child is interested. \\
\hline $\begin{array}{l}\text { Robot } \\
\text { configuration }\end{array}$ & 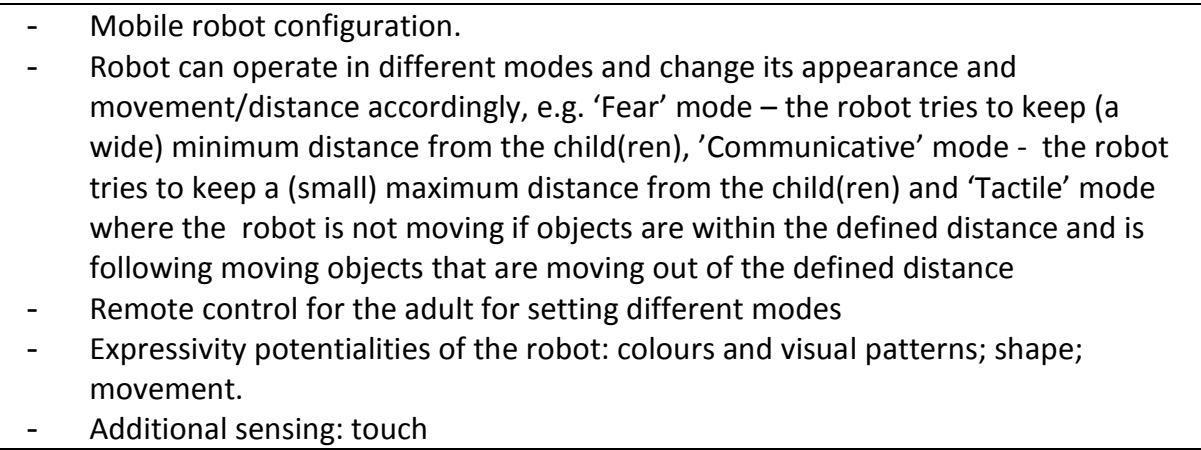 \\
\hline
\end{tabular}

\section{VARIATIONS:}

\section{Variation 1 - Child control}

\begin{tabular}{|l|l|}
\hline $\begin{array}{l}\text { Target } \\
\text { group }\end{array}$ & SMI-MMR \\
\hline Actors & Two children are playing \\
\hline Activity & $\begin{array}{l}\text { In this variation, one child is controlling, via a remote control, the robot behavioural } \\
\text { modes (e.g. 'fear mode' 'communicative mode' etc) whilst the other child is playing. } \\
\text { Thus the child who has the remote control manages the 'friendliness' of the robot, } \\
\text { making it more inclined to approach the other child or more inclined to stay away from } \\
\text { him/her etc. By controlling the robot's behaviour, the child can also delay the robot's } \\
\text { responses by making the robot appear to be 'lazy' in order to encourage the other child } \\
\text { to intensify his/her interaction with the robot. }\end{array}$ \\
\hline
\end{tabular}




\section{Objectives:}

\begin{tabular}{|c|c|c|c|c|}
\hline Area & Educational and therapeutic objectives & AUT & SMI & MMR \\
\hline \multirow{3}{*}{ 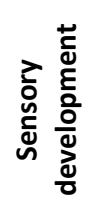 } & $\begin{array}{l}\text { Perceptual functions } \\
\qquad \quad \text { to improve visual perception }\end{array}$ & $\phi$ & $\phi$ & $\theta$ \\
\hline & - to improve tactile perception & $\phi$ & & $\phi$ \\
\hline & - to improve visuospatial perception (spatial awareness) & & & $t$ \\
\hline \multirow{3}{*}{ 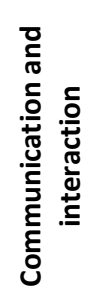 } & $\begin{array}{l}\text { Basic interpersonal interaction } \\
\text { - to improve the ability to respond to social cues }\end{array}$ & $\phi$ & & $\phi$ \\
\hline & - to improve the level of response to others & $\phi$ & & - \\
\hline & $\begin{array}{l}\text { Particular interpersonal relationships } \\
\text { - to encourage participation with classmates }\end{array}$ & & $\phi$ & $\phi$ \\
\hline \multirow{10}{*}{ 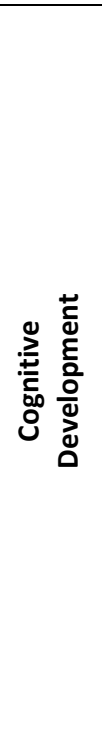 } & $\begin{array}{l}\text { Energy and drive functions } \\
\bullet \quad \text { to improve motivation to act }\end{array}$ & & - & \\
\hline & $\begin{array}{l}\text { Global intellectual functions } \\
\text { - to improve understanding of cause and effect }\end{array}$ & & & \\
\hline & $\begin{array}{l}\text { Higher-level cognitive functions } \\
\bullet \quad \text { to improve abstraction }\end{array}$ & & $\phi$ & 7 \\
\hline & - to improve organization and planning & & $\phi$ & $\phi$ \\
\hline & - to improve cognitive flexibility & & $\phi$ & $\theta$ \\
\hline & $\begin{array}{l}\text { Attention } \\
-\quad \text { to improve focusing attention }\end{array}$ & $\phi$ & $\phi$ & $\phi$ \\
\hline & - to improve the capacity to react to changes in the environment & $\phi$ & $\phi$ & $\theta$ \\
\hline & - to improve the ability to maintain attention & $\phi$ & $\phi$ & $\phi$ \\
\hline & - to improve dividing attention & $\phi$ & $\phi$ & $\phi$ \\
\hline & - $\quad$ to improve joint attention & $\phi$ & $\phi$ & $\theta$ \\
\hline \multirow{5}{*}{ 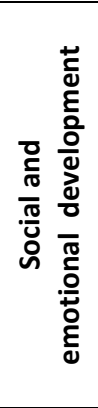 } & $\begin{array}{l}\text { Emotional functions } \\
\text { - to improve regulation of emotion and range of emotion }\end{array}$ & & & $\phi$ \\
\hline & $\begin{array}{l}\text { Experience of self and others } \\
\text { - to improve sense of agency }\end{array}$ & $\theta$ & $\phi$ & $\phi$ \\
\hline & $\begin{array}{l}\text { Engagement in play } \\
-\quad \text { to foster onlooker play }\end{array}$ & $\phi$ & $\phi$ & $\phi$ \\
\hline & - $\quad$ to foster shared cooperative play $\rightarrow$ VARIATION 1 & $\phi$ & $\phi$ & 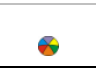 \\
\hline & $\begin{array}{l}\text { Community social and civic life } \\
\text { - to improve the ability to understand and apply play rules }\end{array}$ & & $\phi$ & $\phi$ \\
\hline
\end{tabular}

\subsubsection{Scenario IS10 "Pretending to be a character"}

In the IS10 play scenario the game consists of a symbolic play with the robot, where the robot is a mediator to express feelings and to make simple movements or sequences of simple 
movements or other actions in a pretend play game. The scenario has mainly been developed to be played by children with severe motor impairments as a collaborative play, but it can also be played by children with MMR.

\section{BASIC SCENARIO}

Main target user group: SMI

Additional target user group: MMR

\begin{tabular}{|c|c|}
\hline Play Type & Symbolic play \\
\hline Actors & $\begin{array}{l}\text { Two or more actors are involved in the scenario. These actors are a child and one or } \\
\text { more peers. }\end{array}$ \\
\hline Activity & $\begin{array}{l}\text { The child uses the robot as a mediator to express feelings and to make simple } \\
\text { movements or sequences of simple movements or other actions in a pretence play. } \\
\text { S/he remotely operates the robot in order to change its appearance and behaviour in } \\
\text { pretence play involving peers. } \\
\text { Through a suitable interface (e.g. usable with a single switch scanning mode) the child } \\
\text { directly operates the robot by selecting simple actions among a defined set of possible } \\
\text { choices (for example platform movements, movement of platform components e.g. } \\
\text { arms, action on objects e.g. grasping and lifting, visual and audio feedback, etc) on a } \\
\text { defined set of objects. The robot can also display a set of basic emotions such as } \\
\text { happiness, sadness, fear, surprise, disgust, anger - e.g. becoming red, swelling and } \\
\text { snarling if 'upset' or trembling and whimpering if 'scared' as already mentioned in IS9. } \\
\text { Combining the choice of action, objects and emotion the child can play very simple } \\
\text { symbolic play activities with predefined objects. }\end{array}$ \\
\hline Setting & Classroom, home, therapy session \\
\hline Time & The interaction continues until the child gets tired or bored. \\
\hline $\begin{array}{l}\text { Robot } \\
\text { configuration }\end{array}$ & $\begin{array}{ll}\text { - } & \text { Facial features to be displayed if possible } \\
\text { - } & \text { Acoustics output (pre-recorded messages or sounds) } \\
\text { - } & \text { Moving parts that can be identified as 'body parts' (e.g. arms, head) } \\
\text { - } & \text { sensory feedback: colour, surface texture, size, sound } \\
\text { - } & \text { sensors: audio sensor (to detect the intensity of sound), tactile sensor (to detect } \\
\text { the intensity of touch), proximity sensor (to detect a person/object in the } \\
\text { surroundings of the robot), colour detection (to differentiate between defined } \\
\text { objects) } \\
\text { - Remote control for robot and component movement, selection of 'behaviour } \\
\text { primitives' from defined set }\end{array}$ \\
\hline
\end{tabular}

\section{Objectives:}

\begin{tabular}{|c|c|c|c|c|}
\hline Area & Educational and therapeutic objectives & AUT & SMI & MMR \\
\hline \multirow{2}{*}{ 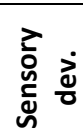 } & $\begin{array}{l}\text { Perceptual functions } \\
\qquad \quad \text { to improve visual perception }\end{array}$ & & $\phi$ & $\phi$ \\
\hline & - to improve proprioception & & & $\phi$ \\
\hline
\end{tabular}




\begin{tabular}{|c|c|c|c|c|}
\hline Area & Educational and therapeutic objectives & AUT & SMI & MMR \\
\hline \multirow{7}{*}{ 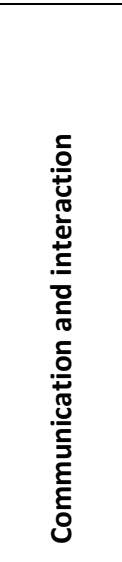 } & $\begin{array}{l}\text { Communicating - Producing - Speaking } \\
\text { - to improve speaking }\end{array}$ & & $\phi$ & 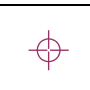 \\
\hline & $\begin{array}{l}\text { Communicating - producing - non verbal messages } \\
\text { - to improve non verbal aspects such as gestures and pointing }\end{array}$ & & & \\
\hline & $\begin{array}{l}\text { Basic interpersonal interaction } \\
\text { - to improve turn-taking }\end{array}$ & & & \\
\hline & - to improve gaze shift and eye contact with others & & & \\
\hline & - to improve the ability to respond to social cues & & & $\phi$ \\
\hline & - to improve level of response to others & & & \\
\hline & $\begin{array}{l}\text { Particular interpersonal relationships } \\
\text { - to encourage participation with classmates }\end{array}$ & & $\phi$ & \\
\hline \multirow{12}{*}{ 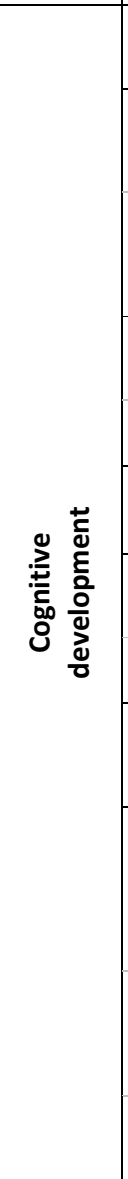 } & $\begin{array}{l}\text { Global intellectual functions } \\
\text { - to improve understanding of cause and effect }\end{array}$ & & & \\
\hline & $\begin{array}{l}\text { Higher-level cognitive functions } \\
\text { - to improve abstraction }\end{array}$ & & $\phi$ & \\
\hline & $\begin{array}{l}\text { Copying } \\
\text { to improve the ability to mirror and imitate simple and complex } \\
\text { movements }\end{array}$ & & $\phi$ & \\
\hline & $\begin{array}{l}\text { Attention } \\
-\quad \text { to improve the ability to maintain attention }\end{array}$ & & $\phi$ & \\
\hline & - to improve joint attention & & $\phi$ & $\phi$ \\
\hline & $\begin{array}{l}\text { Solving problems } \\
-\quad \text { to improve the ability to solve problems }\end{array}$ & & $\phi$ & $€$ \\
\hline & $\begin{array}{l}\text { Thinking } \\
\bullet \quad \text { to foster pretending }\end{array}$ & & - & \\
\hline & - to foster hypothesizing & & $\phi$ & $\phi$ \\
\hline & $\begin{array}{l}\text { Making decisions } \\
\bullet \quad \text { to improve decision-making abilities }\end{array}$ & & $\phi$ & * \\
\hline & $\begin{array}{l}\text { Learning through action with objects } \\
\text { - to improve the ability to carry out actions relating to objects, } \\
\text { toys or materials symbolically, for example, feeding or dressing a } \\
\text { toy animal or doll }\end{array}$ & & $\bullet$ & \\
\hline & $\begin{array}{l}\text { - to improve the ability to carry out actions involving pretence, } \\
\text { substituting a novel object, body part or body movement to } \\
\text { enact a situation or event. }\end{array}$ & & $\theta$ & \\
\hline & $\begin{array}{l}\text { - to improve the ability to engage in make-believe activities } \\
\text { involving imaginary persons, places, things or events }\end{array}$ & & - & - \\
\hline \multirow{4}{*}{ 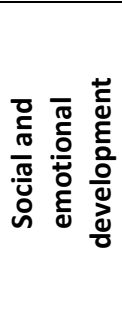 } & $\begin{array}{l}\text { Emotional functions } \\
\text { - to improve regulation of emotion and range of emotion }\end{array}$ & & & - \\
\hline & $\begin{array}{l}\text { Engagement in play } \\
-\quad \text { to foster shared cooperative play }\end{array}$ & & $\phi$ & $\phi$ \\
\hline & $\begin{array}{l}\text { Community social and civic life } \\
\text { - to improve the ability to understand and apply play rules }\end{array}$ & & $\phi$ & $\phi$ \\
\hline & - to improve the ability to negotiate play rules & & & $\phi$ \\
\hline
\end{tabular}




\begin{tabular}{|c|c|c|c|c|}
\hline Area & Educational and therapeutic objectives & AUT & SMI & MMR \\
\hline 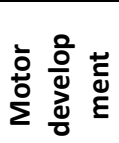 & $\begin{array}{l}\text { Mobility (objects) } \\
\text { - to improve the ability to lift, to carry, to put down [...] objects } \\
\text { through AT devices }\end{array}$ & & - & \\
\hline
\end{tabular}

\section{Using IROMEC Scenarios in Interaction Studies - an example}

The play scenarios presented in this paper can guide the child through different play types (e.g. exercise play, symbolic play, games with rules etc), engaging him/her in turn-taking activities, action and coordination games, and imitative interaction games (for detailed description of play types see Robins et al. 2010b). The play scenarios were implemented and evaluated by the project partners during interaction studies in different countries. The following section briefly summarises the evaluation study in two primary schools in Italy. The study was exploratory in nature and involved only a small group of children, however, it illustrates the use of the IROMEC scenarios in the envisaged context of robot assisted play for children with special needs. Further extensive evaluation of the IROMEC robot will be reported elsewhere.

\subsection{The experimental design}

The main aim of the study was to investigate the achievement of specific educational objectives in play activities with the robot. The study has been conducted in two different schools in Siena (Italy) for almost 3 months with 3 sessions per week. The trials involved 4 children ( 3 female and 1 male) from 6 to 11 years of age, with different disabilities, i.e. global cognitive disability, Tuberous Sclerosis, Attention Deficit Hyperactive Disorder (ADHD) and motor impairment. (Marti \& Iacono, 2011).

The play sessions were organized in individual and group sessions. In the group sessions each child played with 3 or 4 classmates with normal development. One special education teacher and a facilitator attended the trials. They were directly involved in the activity. The sessions 
were defined as adult-facilitated (structured) play conditions for individual sessions and peer to peer play conditions for group sessions. Each session lasted approximately 40 minutes. The sessions were recorded by two cameras. Each session was divided into three steps: Introduction to the robot, Play scenarios, Complete the scenario and Time to say goodbye.

Five different play scenarios were performed by each child (Figure 3):

1) Turn-taking with a mobile robot (IS01, cf. section 2.1.1),

2) Turn-taking for sensory reward (IS02, cf. section 2.1.2),

3) Make it move (IS04, cf. section 2.1.4),

4) Follow me (IS05, cf. section 2.1.5),

5) Get in contact (IS09, cf. section 2.1.9).

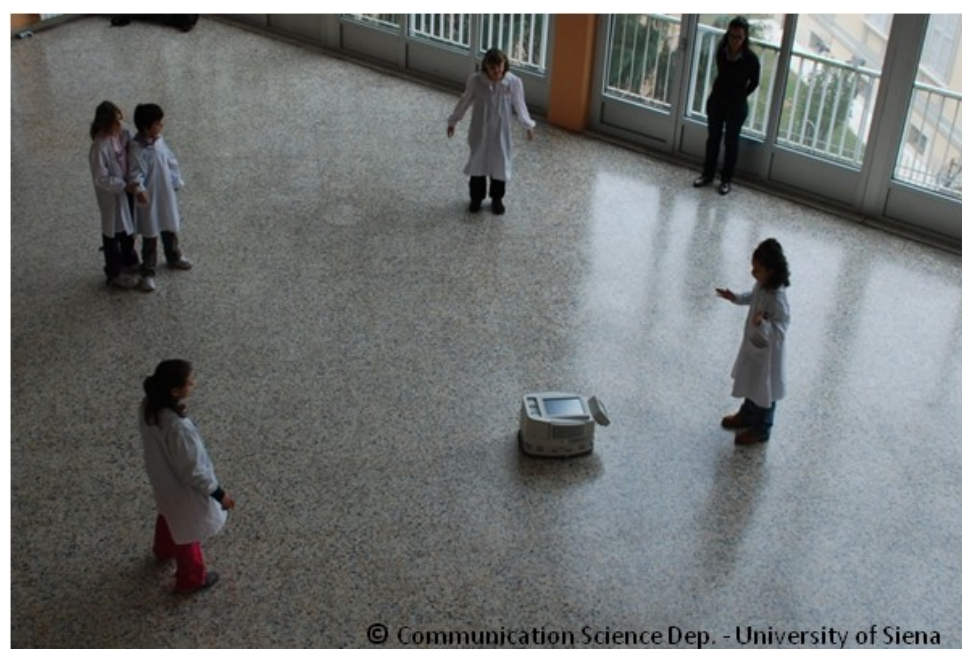

Figure 3 Trials performed at primary school in Siena (Italy)

\subsection{Data Collection Methodology}

The evaluation was performed administering a questionnaire based on a review of consolidated and validated assessment tools (e.g. Vineland Scale of Adaptive Behaviour; Test of Gross Motor Development; Imitation Battery) used to evaluate children's development in different areas.

We asked the special education teachers to fill in the questionnaire twice, namely once before the play sessions (as a pre-test) in order to evaluate a baseline for each child and a second time 
at the end of the play sessions (as a post-test) to evaluate any changes. The questionnaire is divided into items related to five developmental areas: Sensory; Communicational and Interaction; Cognitive; Motor; Social and Emotional. Each area is divided into sub-functions (e.g. the Sensory Development Area is divided into Perceptual functions). Each item on the questionnaire was assessed with a five point Likert scale with nominal values ranging from NEVER to ALWAYS. The questionnaire was composed of 158 items, subdivided into 5 developmental areas and 20 sub-functions. The nominal values from the questionnaire were converted into numerical values $(1=$ NEVER to $5=$ ALWAYS $)$ in order to facilitate the analysis.

\subsection{Results}

The analysis was performed in three different steps: computation of the mean value of the developmental areas and functions (pre- and post- test); computation of the difference between the mean value obtained in post-test and pre-test, and the computation of the number of items that changed between post-test and pre-test. Incomplete items were excluded from the analysis. The number of items we collected differed for each child. For all 4 children we recorded some changes for each developmental area. In particular, we did not record any positive changes for the Sensory developmental area, even if these data were not confirmed from the qualitative analysis or from the comments of the special education teachers. In fact, the video recording of the activity shows a clear interest of the children in the visual and sound interface of IROMEC. The attention of the children was caught mainly by the robot's face. The visual and sound interfaces are an important feature in order to sustain the interaction with children with cognitive disabilities. The Motor development area was the only one which did not report any negative change.

We collected for the children 1 and 4 a total of 144 items while for the children 2 and 3 a total of 147 items. Most of the items were unchanged, as it is reasonable to expect, due to the limited duration of the experiment. However, we recorded for child 1 and child 4 respectively a number 
of 49 and 41 items incremented from the pre-test. These items were related to the Communication and Interaction developmental area and to the Cognitive Development only for child 4. Most of decremented items for child 3 were in the Communication and Interaction area, whilst most of the incremented items were related to the Motor Development area.

\subsection{Discussion}

Some results, although to be considered as preliminary, show a significant improvement for some children. These results are more meaningful if considered in relation to the specific disability. For example child 3 has a severe disability (Tuberous Sclerosis) and motor impairments. She does not possess fine motor skills and has difficulties in controlling her strength of upper limbs. During the sessions she improved her ability to coordinate movements and to control her strength during the interaction with the robot. She did it at the beginning of the sessions with the help of the teacher and was able to do it herself afterwards. These positive improvements underline the ability of IROMEC to support the children in their motor development. Its ability to move autonomously and to follow the children allows them to achieve a better understanding of their body.

Child 2 had a positive increment in two developmental areas and no decrease in the others. This child has difficulties in maintaining the focus of attention on the same activity and his attention span is extremely short. The hyper-activity which characterizes his behaviour was rarely observable during play with the robot. He felt at ease in respecting his turn and the rules of the game.

As a general lesson learnt, we experienced that creating a more inclusive and welcoming atmosphere was important to encourage the conversation and to facilitate better interaction with IROMEC. The presence of the facilitator was not perceived as intrusive by the children. The individual sessions let the disabled child become the main protagonist of the play session. Through the individual sessions the children had the opportunity of getting to know IROMEC 
better and understand the rules of the play scenarios. The group sessions were important to identify interaction dynamics in a peer to peer context. For example, we observed an active involvement of the disabled children's classmates as well as a situation of peer to peer learning. These behaviours were reported by the teachers too.

The younger children preferred the scenarios Make It Move and Turn-Taking with Sensory Reward, whilst the older children preferred the Get in Contact scenario. The emotional states that the children associated with IROMEC from its visual interface were fear and happiness. The ability to recognize emotions and to be able to distinguish between them suggests a developed emotional intelligence. In particular the older children associated the image of a heart that appeared during the symbolic play scenario (Get in Contact) as a way for the robot to mean "I like you!" No spontaneous negative comments were recorded.

\section{Conclusion and future work}

In recent years there have been many examples of robots being used in play activities of children with special needs, for therapeutic or educational purposes (Kozima et al., 2007; Kozima et al., 2009; Lathan \& Malley, 2001; Marti et al., 2005; Michaud et al., 2007; Robins et al., 2005; Robins et al., 2004a; Robins et al., 2004b; Robins et al., 2009; Stiehl et al., 2005; Stiehl et al., 2009). These robots have shown to be useful in promoting spontaneous play in children with developmental disorders, engaging them in playful interactions. Many different research methods were used to conduct evaluations, pointing out the need for a shared framework that would help the process of developing play activities against therapeutic objectives, and the evaluation and integration of research results.

The article presented a set of play scenarios, each with its relevant educational and therapeutic objectives in five key developmental areas (i.e. sensory development, communication and interaction, cognitive development, motor development and social and emotional development). 
Although the play scenarios were originally developed for and tested with the user groups identified in the IROMEC project (i.e. AUT, SMI and MMR) and with the IROMEC robot, the play scenarios may be considered for use with other user groups or in other applications involving human-robot interaction and with other robotic toys.

One example of such application is the use of this framework within the European FP7 project ROBOSKIN (ROBOSKIN, 2011) where there was a need for the development of social play scenarios for tactile interaction with a humanoid robot in order to develop skin-based robot assisted play. Here, once the higher level user requirements for tactile interaction for children with autism were identified (Amirabdollahian et al., 2009; Robins et al., 2010a), the framework of play scenarios and therapeutic objectives presented in this paper was adopted and used in the development of initial tactile play scenarios with the humanoid robot KASPAR (Dautenhahn et al., 2009) that were based on turn-taking and imitation games, together with the related educational and therapeutic objectives relevant for children with autism (Robins \& Dautenhahn, 2010). This example of research in the ROBOSKIN project already demonstrates that the scenarios described in this article can be used in a different context with a different robot.

IROMEC play scenarios have also been used in a recent long-term study involving both the IROMEC robot and the robot KASPAR, see initial results presented in Iacono et al. (2011); Lehmann et al. (2011).

In this article we provided detailed descriptions of 10 novel play scenarios for robot assisted play in relation to specific therapeutic objectives. It is hoped that this work will contribute to further advancement in the field of robot assisted play by providing a common basis for play scenarios that other projects can utilize or build upon. 


\section{References}

Amirabdollahian, F., Robins, B., \& Dautenhahn, K. (2009). Robotic Skin Requirements Based on Case Studies on Interacting with Children with Autism. Paper presented at the "Tactile Sensing" workshop at IEEE Humanoids09, Paris.

Besio., S. (2001). Allowing Children with Motor Impairment to Play, Learn, Learn to Play: A new Biennial Research Project of SIVA. Paper presented at the 3rd conference of the Association for the Advancement of Assistive Technology in Europe (AAATE), Ljubljana, pp. 231-234.

Bruner, J. S., May, A., \& Koslowski, B. (1972). The Intention to Take a Film. New York: Wiley.

Carroll, J. M. (1995). Scenario-based Design: Envisioning Work and Technology in System Development. Wiley: New York.

Dautenhahn, K., C. L. Nehaniv, M. L. Walters, B. Robins, H. Kose-Bagci, N. Assif Mirza, et al. (2009). KASPAR - A Minimally Expressive Humanoid Robot for Human-Robot Interaction Research. Special Issue on "Humanoid Robots", Applied Bionics and Biomechanics, 6(3): 369-397(published by Taylor and Francis.).

Ferland, F. (1977). The Ludic Model: Play, Children with Physical Disabilities and Occupational Therapy. Ottawa: University of Ottawa Press.

Ferrari, E., Robins, B., \& Dautenhahn, K. (2009). Therapeutic and educational objectives in Robot Assisted Play for children with autism Paper presented at the 18th IEEE International Workshop on Robot and Human Interactive Communication - RO-MAN 2009, Toyama, Japan.

Garon, D., Filion, R., \& Doucet, M. (1996). El sistema ESAR: Un método de análisis psicológico de los juguetes. Alicante, Spain.

Gelderblom, G. J., Dijkstra, J., Kronreif, G., \& (2007). User Involvement in IROMEC: Robot Development for Children with Disabilities. Paper presented at the 9-th European Conference for the Advancement of Assistive Technology in Europe, (AAATE07), San Sebastian, Spain pp. 515-519.

Iacono, I., Lehmann, H., Marti, P., Robins, B., \& Dautenhahn, K. (2011). Robots as social mediators for children with autism - A preliminary analysis comparing two different robotic platforms. Paper presented at the IEEE ICDL - EPIROB 2011, first Joint IEEE International Conference on Development and Learning and on Epigenetic Robotics, Frankfurt am Main, Germany.

IROMEC. (2010). URL: http://www.iromec.org last accessed 14/06/10.

Kozima, H., C. Nakagawa, \& Y. Yasuda. (2007). Children-robot interaction: a pilot study in autism therapy. Progress in Brain Research, 164, pp385-400.

Kozima, H., Michalowski, M. P., \& Nakagawa, C. (2009). A playful robot for research, therapy, and entertainment. International Journal of Social Robotics, 1(1) pp 3-18.

Lathan, C., \& Malley, S. (2001). Development of a New Robotic Interface for Telerehabilitation. Paper presented at the EC/NSF workshop on Universal accessibility of ubiquitous computing, Alcácer do Sal, Portugal, p 80-83.

Lehmann, H., Iacono, I., Robins, B., Marti, P., \& Dautenhahn, K. (2011). 'Make it move': Playing cause and effect games with a robot companion for children with cognitive disabilities. Paper presented at the ECCE 2011 - European Conference on Cognitive Ergonomics Designing Collaborative Activities, Rostock, Germany.

Marti, P., Giusti, L., Moderini, C., \& Pollini, A. (2009). A Robotic Toy for Children with special needs: From requirements to Design. Paper presented at the The11th IEEE International conference on rehabilitation robotics (ICORR2009), Kyoto, Japan.

Marti, P., \& Iacono, I. (2011). Learning Through Play With a Robot Companion. Paper presented at the The 11th European Conference for the Advancement of Assistive Technology, AAATE 2011, Maastricht, the Netherlands. 
Marti, P., Pollini, A., Rullo, A., \& Shibata, T. (2005). Engaging with artificial pets. Paper presented at the Proceedings of Annual Conference of the European Association of Cognitive Ergonomics, Chania, Greece.

Michaud, F., Larouche, H., F. Larose, T. Salter, A. Duquette, H. Mercier, et al. (2007). Mobile robots engaging children in learning. Paper presented at the Canadian Medical and Biological Engineering Conf, Toronto.

Piaget, J. P. (1962). Play, dreams, and imitation in childhood. New York: Norton.

Robins, B., Amirabdollahian, F., Ji, Z., \& Dautenhahn, K. (2010a). Tactile interaction with a humanoid robot for children with autism: A case study analysis from user requirements to implementation. Paper presented at the The19th IEEE International Symposium in Robot and Human Interactive Communication (RO-MAN10), Viareggio, Italy, (accepted).

Robins, B., \& Dautenhahn, K. (2010). Developing Play Scenarios for Tactile Interaction with a Humanoid Robot: A Case Study Exploration with Children with Autism. Paper presented at the International Conference on Social Robotics, Singapore 24-25 November

Robins, B., Dautenhahn, K., te-Boekhorst, R., \& Billard, A. (2005). Robotic assistants in therapy and education of children with autism: can a small humanoid robot help encourage social interaction skills? Universal Access in the Information Society, 4:2

Robins, B., Dautenhahn, K., te Boekhorst, R., \& Billard, A. (2004a). Effects of repeated exposure of a humanoid robot on children with autism. In S. Keates, J. Clarkson, P. Langdon \& P. Robinson (Eds.), Designing a More Inclusive World (pp. 225-236). London: Springer Verlag.

Robins, B., Dickerson, P., Stribling, P., \& Dautenhahn, K. (2004b). Robot-mediated joint attention in children with autism: A case study in a robot-human interaction. Interaction studies: Social Behaviour and Communication in Biological and Artificial Systems,, 5:2 John Benjamins Publishing Company, Amsterdam, 161-198.

Robins, B., E. Ferrari, K. Dautenhahn, G. Kronrief, B. Prazak-Aram, G. Gerderblom, et al. (2010b). Developing Scenarios for Robot Assisted Play Informed by User Panels and Field Trials. International Journal of Human-Computer Studies IJHCS 68, pp. 873-898.

Robins, B., K. Dautenhahn, \& Dickerson, P. (2009). From Isolation to Communication: A Case Study Evaluation of Robot Assisted Play for Children with Autism with a Minimally Expressive Humanoid Robot. Paper presented at the Second International conference on Advances in CHI, ACHI09, Cancun, Mexico.

Robins, B., Otero, N., Ferrari, E., \& Dautenhahn, K. (2007). Eliciting Requirements for a Robotic Toy for Children with Autism - Results from User Panels. Paper presented at the 16th IEEE International Workshop on Robot and Human Interactive Communication - RO-MAN 2007, 26-29 August, Jeju island, Korea.

ROBOSKIN. (2011). URL: http://www.roboskin.eu/, last accessed: 14/11/11.

Rosson, M. B., \& Carroll, J. M. (2002). Scenario-Based Design. In J.Jacko \& A. Sears (Eds.), The Human-Computer Interaction Handbook: Fundamentals, Evolving Technologies and Emerging Applications (Vol. v. 53): Lawrence Erlbaum Associates, pp. 1032-1050.

Rozzo, A., Marti, P., Decortis, F., Moderini, C., \& Rutgers, J. (2003). The Design of POGO Story World. In E. Hollnagel (Ed.), Cognitive Task Design. London: Earlbaum.

Saldien, J., Kristof Goris, Selma Yilmazyildiz, Werner Verhelst, \& Lefeber, D. (2008). On the design of the huggable robot Probo. Journal of Physical Agents, Special Issue on Human Interaction with Domestic Robots, Vol 2, (2).

Stiehl, W. D., J. Lieberman, C., C. Breazeal, L. Basel, L. Lalla, \& Wolf, M. (2005). Design of a Therapeutic Robotic Companion for Relational, Affective Touch. Paper presented at the Proceedings of the International Workshop on Robots and Human Interactive Communication.

Stiehl, W. D., Lee, J. K., Breazeal, C., Nalin, M., Morandi, A., Sanna, A., et al. (2009). The Huggable: A Platform for Research in Robotic Companions for Pediatric Care. Paper 
presented at the Creative Interactive Play for Disabled Children Workshop at the 8th International Conference on Interaction Design and Children (IDC 2009), Como, Italy, 2009.

Vygotsky, L. S. (1978). Mind in Society. Cambridge MA: Harvard University Press.

Werry, I., Dautenhahn, K., \& Harwin, W. (2001). Evaluating the response of children with autism to a robot. In R. Simpson (Ed.), Proc. of the RESNA 2001 Annual Conference, Rehabilitation Engineering and Assistive Technology Society of North America (pp. 1419). Arlington: Resna Press.

WHO. (2001). International Classification of Functioning, Disability and Health. Geneva: World Health Organization.

Winnicott, D. W. (1971). Playing and Reality. Middlesex, UK: Penguin Books Ltd. 